\title{
Političko-proračunski ciklusi na uzorku hrvatskih gradova
}

Mačkić, Velibor

Source / Izvornik: Odabrani prijevodi, 2014, 5, 1 - 28

Journal article, Published version

Rad u časopisu, Objavljena verzija rada (izdavačev PDF)

https://doi.org/10.3326/op.21

Permanent link / Trajna poveznica: https:/urn.nsk.hr/urn:nbn:hr:242:413564

Rights / Prava: Attribution-NonCommercial-NoDerivatives 4.0 International/ImenovanjeNekomercijalno-Bez prerada 4.0 međunarodna

Download date / Datum preuzimanja: 2023-04-26

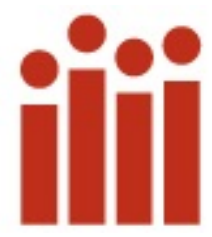

Repository / Repozitorij:

Institute of Public Finance Repository

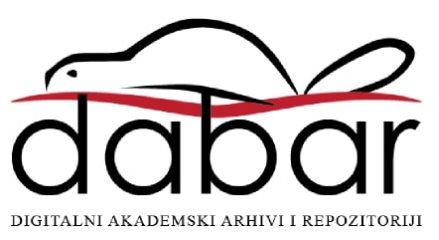


Institut za

javne financije

Smičiklasova 2I | Zagreb

www.ijf.hr | ured@ijf.hr

T: oI/4886-444 | F: OI/48I9-365

\section{OdABRANI}

\section{PRIJEVODI}

\author{
ISSN $1847-7445$
}

BR. 2I/I4

citirati: Mačkić, V., 20I4. “Political budget cycles at the municipal level in Croatia". Financial Theory and Practice, 38 (I), I-35.

http://www.fintp.hr/upload/files/ft $\mathrm{p} / 2014 / \mathrm{I} /$ mackic.pdf

Svi Odabrani prijevodi dostupni su na: http://www.ijf.hr/hr/publikacije/ca sopisi/I2/odabrani-prijevodi/III/

\section{POLITIČKO-PRORAČUNSKI GIKLUSI NA UZORKU HRVATSKIH GRADOVA}

\author{
VELIBOR MAČKIĆ, UNIV.SPEC.OEC.” \\ PRETHODNO PRIOPĆENJE* \\ JEL: D72 \\ DOI: $10.3326 /$ op.21
}

\section{SAŽETAK}

U radu se istražuju političko-proračunski ciklusi (engl. political-budget cycles, PBC) na uzorku od Ig županijskih središta, Grada Zagreba i Pule. U promatranom razdoblju od 2002. do 2011. održana su tri ciklusa parlamentarnih izbora (2003., 2007. i 20II.) i dva ciklusa lokalnih izbora (2005. i 2009.), te su svi rezultati prikazani na razini odabranih gradova. Rezultati ne potvrđuju postojanje oportunističkog PBC-a i upućuju na restrukturiranje ukupnih rashoda uslijed institucionalnih ograničenja kad se zajednički analiziraju svi izbori i kad se analiziraju parlamentarni izbori. Analiza lokalnih izbora potvrđuje postojanje Rogoffovog modela PBC-a temeljenog na asimetričnosti informacija. Uz empirijsku analizu prikazani su različiti teorijski modeli PBC-a i pregled empirijskih istraživanja o postojanju PBC-a u razvijenim i tranzicijskim zemljama, te u zemljama u razvoju.

Ključne riječi: političko-proračunski ciklusi, izbori, dinamička panel analiza, Hrvatska
Autor posebno zahvaljuje mentorici prof. dr. sc. Mirjani Dragičević i kolegici dr. sc. Blanki
Škrabić Perić za svu pomoć prilikom pisanja i istraživanja. Također, posebna zahvala ide i trima
anonimnim recenzentima na njihovim korisnim komentarima i prijedlozima.
** Primljeno: I. lipnja 20I3.
Prihvaćeno: 2O. prosinca 20I3. Članak je osvojio nagradu u kategoriji redovitih radova zaklade Prof. dr. Marijan Hanžeković za 20I3. godinu.

Ekonomski fakultet u Zagrebu, Trg J. F. Kennedyja 6, Ioooo Zagreb, Hrvatska e-mail: vmackic@efzg.hr 


\section{UVOD}

U kontekstu prijeđenog tranzicijskog puta od 1990-ih problem proračunskih deficita svi hrvatskih jedinica vlasti (nacionalna, regionalne i lokalne) ukazuje na potrebu analiziranja političkih ograničenja u procesu formiranja i provođenja proračunske i ekonomske politike. Politička ograničenja rezultat su heterogenosti preferencija sudionika unutar teorije javnog izbora (političara, birača, birokrata i interesnih skupina) i njihovih međusobno suprotstavljenih interesa. Javljaju se uslijed (samo)zainteresiranog ponašanja političara na vlasti, koji pritisnuti brigom oko reizbora, mogu utjecati na suboptimalnu alokaciju proračunskih sredstava i kreirati proračunski deficit. U tom svjetlu, šire sagledavanje ograničenja može u bitnome doprinijeti saznanjima samih nositelja ekonomske politike, ali i istraživača, birača i svih ostalih aktera javnog izbora. Dodatno, veličina i utjecaj države u ekonomiji (promatran kao udio BDP-a koji se raspodjeljuje političkim odlukama) od prevelike je važnosti da bi fokus ostao isključivo na analizi tržišnih odluka, te da bi se same političare i njihove preferencije držalo egzogenom varijablom.

Političko-proračunski ciklusi (PBC) intenzivno se proučavaju i s teorijskog (npr. Rogoff i Siebert, I988.; Rogoff, 1990.; Shi i Svensson, 2002.; Drazen i Eslava, 2006.) i s empirijskog aspekta (npr. Persson i Tabellini, 2002. ; Brender i Drazen, 2004.; Alt i Lassen, 2006.; Schneider, 2010.) na različitom uzorku zemalja i pomoću različitih metodoloških instrumenata. Unatoč važnosti političkih ograničenja pri formulaciji i provođenju optimalnih ekonomskih politika, PBC predstavlja područje koje u Hrvatskoj nije istraženo, posebno ne na lokalnoj razini.

Modeli PBC-a predstavljaju jednu od najaktivnijih grana istraživanja unutar nove (pozitivne) političke ekonomije (NPE). Uslijed teorijske utemeljenosti i empirijske potvrđenosti gotovo su u cijelosti zamijenili dotadašnja istraživanja fokusirana na političko-poslovne cikluse (engl. political-business cycles, PPC). Modele PBC-a možemo definirati kao periodičku fluktuaciju fiskalne politike uslijed izbornih ciklusa. Zavisno od vrste modela, fluktuacija može poprimiti oblik proračunskog deficita, porasta ili promjene strukture javnih izdataka, te pada javnih prihoda. Iz toga slijedi primarni cilj rada, kojim će se pokušati utvrditi koji je od postojećih teorijskih modela PBC-a primjenjiv u Hrvatskoj.

Temeljna hipoteza rada je da u Hrvatskoj postoje oportunistički PBC-i na razini gradova, a dodatna da stranačka podudarnost političara na vlasti na središnjoj i gradskoj razini povećava izdatke gradskih proračuna. Prema saznanjima autora, u domaćoj znanstvenoj literaturi, ne postoji niti jedan rad koji empirijski testira postojanje PBC-a na lokalnoj razini u Hrvatskoj. Ključan doprinos rada postojećoj literaturi stoga predstavlja analiza rezultata parlamentarnih i lokalnih izbora zajedno, te posebno lokalnih i posebno parlamentarnih izbora na odabranom uzorku gradova.

Rezultati istraživanja, koji obuhvaćaju i lokalne i parlamentarne izbore, te posebno parlamentarne izbore, ne potvrđuju temeljnu i dodatnu hipotezu rada. U izbornim godinama ukupni rashodi se smanjuju i rezultiraju nižom razinom proračunskog deficita. Političari na vlasti, uslijed institucionalnih ograničenja visine zaduženja, pribjegavaju oportunističkoj manipulaciji unutar stavki ukupnih rashoda. Drugim riječima, smanjuju kapitalne i povećavaju tekuće izdatke. Analiza lokalnih izbora, međutim, potvrđuje postojanje oportunističkog modela PBC-a i upućuje na Rogoffov model asimetričnosti informacija kao optimalni PBC model. Naime, porast proračunskog deficita u izbornim godinama, zajedno s porastom prosječnog broja zaposlenih u tijelima i kod korisnika odgovara teorijskim pretpostavkama navedenog modela. Oba rezultata upućuju na oportunističko ponašanje političara na vlasti i rentijersku ulogu birokracije u izbornom procesu. 
U drugom dijelu rada predstavljeni su osnovni pojmovi NPE i teorije javnog izbora (TJI) kao "krovnih" područja unutar kojih su se razvili modeli PPC-a i PBC-a. U trećem poglavlju prikazana su tri ključna modela PBC-a: asimetričnosti informacija, moralnog hazarda i asimetričnosti preferencija političara na vlasti, koji čine teorijsku osnovu daljnje analize. U četvrtom poglavlju dan je pregled empirijskih istraživanja o postojanju PBC-a u razvijenim i tranzicijskim zemljama, te zemljama u razvoju. Podaci, metodologija i empirijski rezultati prikazani su u petom, a u šestom poglavlju daje se osvrt na dobivene rezultate empirijske analize obzirom na teorijske pretpostavke prezentiranih modela PBC-a, te smjer daljnjih istraživanja.

\section{NOVA POLITIČKA EKONOMIJA I TEORIJA JAVNOG IZBORA}

Istraživačko područje NPE nastaje na temeljima makroekonomske politike (Lucasove kritike), teorije racionalnih očekivanja i TJI (Persson i Tabellini, 2000:2-3). Iako temeljena na TJI (metodološki individualizam $^{\mathrm{I}}$ i maksimalizacija korisnosti), NPE postaje primarno zainteresirana za analizu ekonomskih učinaka političkog djelovanja. Drugim riječima, NPE postojeće institucije uzima kao dana ograničenja u procesu optimizacije, bez eksplicitno izražene namjere da ih mijenja.

Drazen (2000:7) ističe da NPE pokušava dati odgovor na pitanje kako politička (ne samo tehnološka ili informacijska) ograničenja utječu na izbor politika koje odstupaju od optimalne politike, te objasniti ishode do kojih dovode. Osnove NPE nalaze se u heterogenosti sudionika i sukobu interesa koji rezultiraju političkim ograničenjima. Upravo utjecaji politike na ekonomiju ogledaju se u mehanizmima rješavanja tih sukoba.

Unutar literature, ekonomski učinci političkog djelovanja dijele se na PPC i PBC. Teorijska i empirijska istraživanja navedenih fenomena proizlaze iz TJI koja, kao interdisciplinarno područje istraživanja, ujedinjuje teorijske paradigme ekonomije i politologije i primjenjuje ih u analizi ponašanja ključnih sudionika (političara, birača, birokrata i interesnih skupina). TJI možemo definirati kao posebnu formu "ekonomskog imperijalizma", odnosno ekonomsku teoriju politike ili sukladno Buchananu (2005:8) kao "politiku bez romantike". Ključne pretpostave TJI su samozainteresiranosti pojedinaca, metodološki individualizam i shvaćanje politike kao razmjene (Udehn, 2003:I54). Iz njih slijedi ponašanje sudionika koji pokušavaju maksimalizirati vlastitu korisnost uz dana ograničenja.

U tom procesu izbori imaju dvojaku funkciju. Prvo, oni uključuju političare i njihove preferencije $u$ ekonomske modele čime modeli postaju "bogatiji” i realističniji. Sadržavajući interakciju svih sudionika, modeliraju se i sukobi ekonomskih agenata uslijed međusobno heterogenih preferencija. Drugo, izbornim procesom birači odlučuju o samoj kolektivnoj akciji (npr. njenom početku/završetku, intenzitetu, smjeru djelovanja).

Sudionike TJI u međusobnoj interakciji obilježava odnos "agenta” i "principala” u kojem im se preferencije, u većini slučajeva, ne podudaraju. Pritom "agent” (političar) može izigrati "principala” (birača) uslijed asimetričnosti informacija prije, tokom i/ili nakon izbornog razdoblja. Nakon izbora, slijedi usuglašavanje i donošenje javnih politika za čije provođenje je zadužen treći sudionik birokracija. Bitnu ulogu imaju i interesne skupine koje stvaraju pritisak kako bi utjecale na ishod kolektivnog odlučivanja u svoju korist.

\footnotetext{
${ }^{\text {I }}$ Pojam označava da je u središtu analize pojedinac i njegov (racionalan) izbor. Arnsperger i Varoufakis (20o6.) navode da metodološki individualizam podrazumijeva ideju po kojoj sva društveno-ekonomska objašnjenja treba tražiti na razini individualnog ekonomskog agenta.

${ }^{2}$ Termin je izveden u radovima: Tullocka (1972.), Stieglera (1984.) i Udehna (2003.).
} 
McLean (1997:39, 4I) političare analizira kao poduzetnike koji pribavljaju osobita javna dobra i “ideološke poduzetnike”. Prve, uz ponudu i trgovanje javnim dobrima karakterizira i sklonost trgovanju privatnim dobrima. Njihova poduzetnička uloga kod izbornog tijela predstavlja osnovu za reizbor na javnu funkciju. Nasuprot njima, političare "ideološke poduzetnike" istinski zanima sadržaj politike i političkog, te oni osiguravaju javna dobra bez obzira na problem slobodnog jahača/neplatiše (engl. free rider). "Ideološki poduzetnici” za svoj napor ne zahtijevaju nikakvu protučinidbu i svoj posao shvaćaju kao poziv.

Birači predstavljaju racionalne i samozainteresirane sudionike usporedive s potrošačima na tržištu. Glasovanjem žele maksimalizirati svoju funkciju zadovoljstva, ali najveći problem u analizi ponašanja birača leži u tome da oni ne znaju kako glasovati za vlastite interese. Trošak dolaska do informacija, u (pred)izbornom razdoblju, je prevelik za racionalnog homo economicusa. Dodatno, ako informacija nema ili su asimetrične, optimalna je strategija za svakog birača da se ponaša kao racionalni ignorant. ${ }^{3} \mathrm{U}$ tom slučaju, zanemaruju se predizborna događanja i glasuje se preko ideološke matrice. Upravo ta kombinacija racionalne ignorancije, ideološkog glasovanja i "problema potpune ponude"4 navodi političare na sub optimalno ponašanje.

Prema Niskanenovom modelu birokracije, birokrati će težiti maksimalizaciji vlastitog proračuna zato jer ne mogu prisvojiti dobit (McLean, 1997:IOO-IOI). Budući da su monopolistički opskrbljivači svojih dobara, birokrati na taj način osiguravaju naknadu preko raznih povlastica: veći uredi, više plaće, javni ugled, itd. Većina teoretičara javnog izbora pritom naglašava da će birokrati težiti proizvoditi više nego što to političari (a vrlo vjerojatno i birači) žele, ili će to raditi po većoj cijeni (Lemieux, 2004:27). U literaturi se naglašava uloga asimetričnosti informacija ili moći birokracije da sastavlja dnevni red (Mueller, 2003:333, 342-343).

Interesne skupine su de facto grupe pojedinaca sa zajedničkim interesom koje provode kolektivne akcije: prosvjedi, lobiranje, financiranje kampanja političkih stranaka, itd. Cilj im je utjecati na ishod kolektivnih odluka, koje vrlo često imaju značajke javnog dobra. Njihovo djelovanje nerijetko se svodi na čvrsto povezivanje s onim političkim opcijama za koje vjeruju da će najbolje predstavljati njihove interese, u zamjenu za podršku na izborima. Odnosno, promicanje zajedničkog interesa svojih članova, na štetu drugih, osnovni je razlog ulaska interesnih skupina u politički proces.

\section{POLITIČKO-PRORAČUNSKI GIKLUSI}

Ishodi političkih odluka imaju ekonomske učinke vidljive u kretanju ekonomskih varijabli i instrumenata. Modeli PPC-a predstavljaju cikluse u (makro)ekonomskim varijablama: stopi nezaposlenosti, inflacije i proizvodnje, koji su potaknuti izbornim ciklusom. Obzirom na hipotezu racionalnih očekivanja i na motive političara na vlasti (oportunistički nasuprot stranački svrstani engl. partisan) postojeće modele PPC-a možemo podijeliti u četiri velike skupine: adaptivni oportunistički, adaptivni stranački svrstani, racionalni oportunistički i racionalni stranački svrstani model PPC-a (Alesina, I988:I6). Drazen (2000:259) podjelu nadopunjuje i tzv. "Hibbsovim racionalnim modelom mijenjajućih ciljeva” koji predstavlja sintezu prethodnih u okruženju karakteriziranom racionalnim očekivanjima.

\footnotetext{
${ }^{3}$ Ali i racionalna ignorancija je asimetrična pri čemu bitnu ulogu imaju interesne skupine i političari na vlasti.

${ }^{4}$ Stanje u kojem niti jedan od programa koji se nudi biračima ne odražava u cijelosti njihove preferencije.
} 
Modeli PBC-a predstavljaju periodičku fluktuaciju u fiskalnoj politici nastalu uslijed izbornih ciklusa (Shi i Svensson, 2003:67), odnosno porast javnih izdataka (ukupnih ili u pojedinim stavkama), kreiranje proračunskog deficita, te smanjenje javnih prihoda u izbornoj godini. Ključna razlika između modela PBC-a i PPC-a je u tome što se prvi koncentriraju na analizu instrumenata koji su u nadležnosti političara. Različiti modeli PBC-a proučavaju učinke do kojih dovode politički pritisci usmjereni na stvaranje proračunskog deficita i porast javnih izdataka. Jednako kao i kod modela PPC-a, politički pritisci mogu poprimiti dva oblika: oportunističke i stranački svrstane. U prvom slučaju, oportunistički političar može povećati ukupne javne izdatke ili pojedine proračunske stavke usmjerene prema pojedinim skupinama kako bi povećao mogućnost reizbora. Alternativno, političar na vlasti može biti pod “obvezom" spram određene skupine birača koja preferira određene javne izdatke (Lohmann, 2006:534).

Sukladno Muellerovoj hipotezi o etičnom biraču koja se fokusira na ekonomsko glasovanje, birač ima funkciju cilja u kojoj se nalaze dvije varijable: osobna i društvena korisnost. ${ }^{5}$ Birači, u modelima PBC-a, prilikom glasovanja vrednuju isključivo izravnu, vlastitu korist od vladinih programa. Budući da su informacije asimetrične, njihovo glasovanje označeno je kao racionalno retrospektivno, to jest ono slijedi iz opaženih rezultata rada političara na vlasti tokom prethodnog mandata (Alesina i dr., 1997:2236). Na taj način birači pokušavaju ustvrditi koliko političari pridonose njihovoj funkciji korisnosti. Racionalni birač će pritom reagirati na predizborne manipulacije, na primjer kada političari pokušavaju signalizirati vlastitu razinu visoke kompetentnosti pa podižu javnu potrošnju i snižavaju poreze. Odnosno, kada u (pred)izbornom razdoblju mijenjaju strukturu javnih izdataka. U tim uvjetima, poticaji političara da manipuliraju proračunskim stavkama i stvaraju proračunski deficit, zavise prvenstveno od fiskalnih preferencija birača (preferiraju li "štedljive” ili "rastrošne” političare), te o transparentnosti samog proračunskog procesa.

Shi i Svensson (2003:69-70) razlikuju dvije skupine modela PBC-a: signalne, koji se temelje na asimetričnosti informacija o kompetentnosti političara na vlasti, i modele koji uključuju moralni hazard. Navedenu podjelu proširuju Drazen i Eslava (2006:I6) modelom asimetričnosti preferencija političara na vlasti u kojem se uz razinu izdataka promatra i struktura izdataka među biračima.

Ključni razlog za proučavanje PBC-a predstavlja empirijska potvrda ciklusa, koji su jači kada se promatraju instrumenti makroekonomske politike nasuprot makroekonomskih rezultata (Drazen, 2000:242-244). Pritom, empirija jasno upućuje da je manipulacija instrumenata makroekonomske politike vidljivija u slučaju fiskalne, nego u slučaju monetarne politike, kod političara na vlasti koji oportunističkim ekonomskim politikama žele osigurati reizbor (Snowdon i Vane, 2005:536). Potonje slijedi iz Rogoffovog koncepta konzervativnog središnjeg bankara čiji je cilj stabilnost cijena (Snowdon i Vane, 2005:552). Ciklusi koji nastaju slabijeg su intenziteta i kraći, ali empirijska prednost u istraživanju PBC-a ogleda se u tome da je jednako moguće istraživati cikluse na nacionalnoj i na lokalnoj razini.

\footnotetext{
${ }^{5}$ Mueller (2003:298-299) ta dva člana naziva egotropskom i sociotropskom varijablom u funkciji cilja koju birač pokušava maksimalizirati prilikom glasovanja. Egotropska varijabla mjeri očekivanja birača vezana uz djelovanje vlade na biračev vlastiti dohodak, zaposlenost, itd. Sociotropska varijabla mjeri očekivanja birača vezano uz gospodarstvo općenito, odnosno blagostanje svih građana.
} 


\section{I. MODEL TEMELJEN NA ASIMETRIČNOSTI INFORMAGIJA}

Model se temelji na signalima koje političari na vlasti šalju svojoj izbornoj bazi u obliku nižih poreza i/ili viših razina javnih izdataka. Cilj je da se političari na vlasti, u (pred)izbornom razdoblju, pokušaju prikazati kompetentnijima nego što to stvarno jesu. Na taj način, stvaraju privid da mogu osigurati danu razinu javnih usluga uz manji iznos javnih sredstava. ${ }^{6}$

Osnovni argument modela jest da birači preferiraju javne izdatke, ali konstantno podcjenjuju porezni trošak, odnosno pate od "fiskalne iluzije". Problem je još izraženiji, ako su troškovi odgođeni, pa birači podržavaju političara koji može pružiti visoku razinu javnih izdataka financiranu zaduženjem, a smjenjuju onog koji to nije u stanju.

\section{I.I. ROGOFF-SIEBERTOV MODEL POLITIČKO-PRORAČUNSKOG GIKLUSA}

Model PBC-a Rogoffa i Sieberta iz 1988. pretpostavlja da svaki političar ima razinu kompetentnosti nepoznatu biračkom tijelu. Zbog toga birači, prilikom glasovanja, formiraju racionalna očekivanja temeljem uočenih rezultata fiskalne politike tokom mandata. Odnosno, kompetentni političar na vlasti, pokušat će tu kompetentnost signalizirati provodeći ekspanzivnu fiskalnu politiku, što će rezultirati deficitom u predizbornom razdoblju. Nekompetentni političar na vlasti će ekspanziju izbjeći. Razlog tome je što političar na vlasti, neovisno od razine kompetentnosti, jednako brine o reizboru i društvenom blagostanju.

Izbori se održavaju svake dvije godine i političar na vlasti osigurava poznatu fiksnu razinu javnih usluga koja je rezultat distorzivnog (npr. izdavanje obveznica) i nedistorzivnog poreza, te kompetentnosti političara na vlasti (Rogoff i Siebert, 1988:5). Kompetentnost političara ogleda se u količini i strukturi javnih prihoda, te slijedi MA(I) $)^{7}$ proces što implicira da se kompetentnost ne signalizira izvan izbornog razdoblja. Birači u modelu temelje svoj izbor obzirom na povećanje/smanjenje individualne funkcije korisnosti. Budući da su identični, promatramo reprezentativnog birača, koji će, ceteris paribus, preferirati kompetentnog političara koji može financirati javna dobra isključivo nedistorzivnim porezima koji dodatno ne umanjuju iznos dohotka.

Na početku izbornog razdoblja, birači primaju prvi signal, tj. razinu nedistorzivnog poreza koji političar određuje. Tek nakon izbora birači uočavaju drugi signal, odnosno gubitak dohotka (npr. troškovi financiranja duga). U izbornom razdoblju političarima na vlasti to otvara mogućnost da, kreiranjem proračunskog deficita, signaliziraju biračima veću razinu kompetentnosti, jer su u stanju pružiti više javnih dobara za dani iznos (nedistorzivnih) poreza (Rogoff i Siebert, 1988:5-II).

\section{I.2. ROGOFFOV MODEL POLITIČKO-PRORAČUNSKOG GIKLUSA}

U Rogoffovu modelu iz 1990. javna dobra dijele se na "potrošna” i “investicijska”. Predizborne manipulacije ogledaju se u strukturi javnih izdataka, odnosno u smanjenju kapitalnih izdataka za javna “investicijska” dobra, te povećanju transfera i tekuće potrošnje. U model se uvodi i ego renta političara na vlasti koja predstavlja nenovčanu korist od boravka na vlasti (npr. čast), ali “... koja ne isključuje mogućnost rentijerskog ponašanja” (Rogoff, 1990:2).

\footnotetext{
${ }^{6}$ Rogoff i Siebert (1988:2) definiraju kompetentnost upravo kao iznos minimalnih javnih prihoda potreban kako bi se osigurala dana razina javnih usluga.

${ }^{7}$ MA(I) proces označava model pomičnih prosjeka koji je konceptualno linearna regresija, odnosno vremenski niz čija je vrijednost tekućeg perioda povezana s greškama relacije tekućeg i prethodnih razdoblja.
} 
Sukladno modelu iz 1990., kompetentnost političara slijedi MA(I) proces i analizira se proizvodna funkcija javnih dobara, ali u per capita iznosima. Proizvodnja javnih dobara ovisi o iznosu (nedistorzivnog) poreza i kompetentnosti političara, ${ }^{8}$ odnosno kompetentniji političar bit će u stanju ponuditi javna dobra uz niži iznos poreza. Budući da birači mogu uočiti iznos poreza i količina javnih "potrošnih" dobara u vremenu $t$, odnosno u izbornom razdoblju, jasan je poticaj političara koji će težiti povećanju javnih "potrošnih” dobara nauštrb javnih “investicijskih” dobara koje birači mogu uočiti tek $\mathrm{u}$ razdoblju $t+\mathrm{I}$. Točna kompetentnost političara bit će jasna tek $\mathrm{u}$ razdoblju $t+\mathrm{I}$. Na taj način, birač $\mathrm{u}$ trenutku glasovanja ne zna je li veća ponuda dobara i usluga rezultat veće kompetentnosti političara na vlasti ili je rezultat fiskalne manipulacije.

\subsection{MODEL TEMELJEN NA MORALNOM HAZARDU}

U modelu PBC-a temeljenom na moralnom hazardu, ni birači ni političari na vlasti, ne znaju točnu razinu kompetentnosti političara na vlasti. Kompetentnog političara definira sposobnost kreiranja više javnih dobara bez dodatnog povećanja poreznog tereta. Najlakši način da to napravi je zaduživanjem, kojeg birači postaju svjesni tek nakon izbora. Na taj način, svi političari, neovisno od razine kompetentnosti, stvaraju proračunski deficit u predizbornom razdoblju.

Ponuda javnih dobara ovisi o kompetentnosti političara na vlasti, porezima, posuđivanju, te funkciji troškova javnog duga. Kompetentnost političara na vlasti također slijedi MA(I) proces, što implicira da ista razina kompetentnosti ne traje više od dva razdoblja. Upravo nakon ta dva razdoblja održavaju se izbori.

Na početku razdoblja $t$ političar odlučuje o iznosima poreza i zaduženja. Tokom promatranog razdoblja dolazi do šoka u kompetentnosti političara na vlasti. Rezultat šoka je ex ante nesigurnost samih političara oko mogućnosti transformiranja dostupnih resursa (javnih prihoda) u javna dobra i usluge, odnosno vlastite kompetentnosti. Budući da se izbori održavaju na kraju promatranog perioda, sposobnost birača da točno procijene odluke koje donosi političar na vlasti razlikuje se zavisno o razini informacija s kojom raspolažu. Udio informiranih birača $\sigma$ znat će točan iznos oporezivanja, javnog duga i javnih dobara, u trenutku glasovanja. Udio neinformiranih birača $(1-\sigma)$ imat će na raspolaganju jedino podatke o varijablama koje direktno utječu na njihovu razinu korisnosti (iznos javnih dobara i visina oporezivanja). Iz navedenog slijedi, da će političarima biti to lakše manipulirati fiskalnim instrumentima u predizbornom razdoblju, što je udio neinformiranih birača veći. Model implicira, da će zemlje koje imaju nisku informiranost birača i velike "ego" rente, bilježiti visoke iznose javnog duga, ali i da će "ego" rente opadati razvojem institucija, te većom transparentnošću proračunskog procesa (Shi i Svensson, 2006:1376-1377).

\subsection{MODEL ASIMETRIČNOSTI PREFERENGIJA POLITIČARA NA VLASTI}

Drazen i Eslava (2006.) razvili su PBC model u kojem političari na vlasti utječu na birače usmjeravajući državnu potrošnju na određenu skupinu birača, a na štetu drugih skupina ili drugih izdataka. Ciljani oblici potrošnje, usmjereni "korisnijim" biračima, omogućavaju izborne manipulacije koje neće biti vidljive $\mathrm{u}$ ukupnim javnim izdacima $\mathrm{i}$ /ili proračunskom deficitu. Potonje je posebno važno za tzv. "stare" demokracije, u kojima empirijska istraživanja potvrđuju da su birači "fiskalni konzervativci” i kažnjavaju političare koji stvaraju proračunske deficite (Eslava, 20II:22).

\footnotetext{
${ }^{8}$ Rogoff (I990:23) kompetentnost političara poistovjećuje s razinom administrativnog koeficijenta inteligencije.
} 
U modelu birači znaju kako je financiran rast izdataka i zanima ih hoće li ta struktura izdataka biti u njihovu korist i nakon izbora. Javna potrošnja pritom može imati sljedeće oblike:

- geografski koncentrirani investicijski projekti (uža definicija pogodovanja nekim skupinama birača prije izbora (engl. pork barrel spending),

- izdaci i transferi usmjereni specifičnoj demografskoj skupini,

- porezne olakšice određenim sektorima.

Ključ kreiranja PBC-a su tzv. policy preferencije političara koje su nepoznate biračima. Prateći izdvajanja za javna dobra u pojedinoj regiji u proteklom periodu, birači ih pokušavaju otkriti. Pritom se pretpostavlja da političar ima neuočene preferencije prema skupini birača i tipovima potrošnje koje su konzistentne tijekom vremena. Na temelju izdvajanja za javna dobra u nekoj regiji, birač može zaključiti koliko političar stvarno preferira tu regiju u vremenu $t$ (izbornom razdoblju) i koje su njegove preferencije u budućnosti. Odnosno, može racionalno procijeniti očekivane buduće koristi ako ta stanka bude na vlasti (Drazen i Eslava, 2006:4-I4).

\section{PREgLed EMPIRIJSKIH ISTRAŽIVANJA O POLITIČKO-PRORAČUNSKIM GIKLUSIMA}

U ovom dijelu rada, prikazano je osam istraživanja koja empirijski testiraju postojanje PBC-a u zemljama OECD-a, temeljem teorijskih modela asimetričnosti informacija ili moralnog hazarda. Analize u svim navedenim radovima provedene su ili statičkim ili dinamičkim panel modelom. Šest istraživanja provedeno je na lokalnim jedinicama vlasti, a dva na razini nacionalnih gospodarstava. Rezultati u četiri istraživanja potvrđuju postojanje PBC-a, dok Rose (2006:407-43I) upućuje da pojava PBC-a ovisi o institucionalnim ograničenjima unutar promatranih saveznih država SAD-a. Zanimljivi su i rezultati istraživanja saveznih pokrajina Zapadne Njemačke, u kojima Seitz (2000:I83-218) i Schneider (2OIO:I25-I5O) opovrgavaju postojanje PBC-a, dok ga Galli i Rossi (2002:283-3O3) potvrđuju. U tablici I nalazi se popis istraživanja koji obuhvaća: autore, metodologiju, varijable i zaključke istraživanja.

Pregled istraživanja o postojanju PBC-a na uzorku tranzicijskih zemalja i zemalja u razvoju obuhvaća trinaest istraživanja od kojih njih deset potvrđuju postojanje PBC-a. Metodologija istraživanja bazirala se na primjeni statičke ili dinamičke panel analize na velikom broju zemalja, odnosno analizi vremenskih serija. Brender i Drazen (2009:2203-2220), nisu testirali postojanje i značajnost proračunskih varijabli u izbornom razdoblju, već su pokušali utvrditi pomaže li oportunističko kreiranje ciklusa u izbornoj godini u reizboru pomoću LOGIT metode, ${ }^{9}$ pa se njihovo istraživanje izdvaja od ostalih. Akhmedov i Zhuravskaya (2004:I3OI-I338) pak kombiniraju statički panel model i LOGIT analizu. Metodologija, varijable i zaključci istraživanja nalaze se u tablici 2, kronološki poredani tako da su prvo prezentirana istraživanja u tranzicijskim zemljama, a zatim ona u zemljama u razvoju, tj. istraživanja koja obuhvaćaju i razvijene i zemlje u razvoju.

\footnotetext{
${ }^{9}$ LOGIT ili logistička regresija predstavlja poseban oblik regresijske analize u kojoj je zavisna varijabla binarna (Hair i dr., 1995:I30). U istraživanju Brendera i Drazena (2008:2203-2220) zavisna binarna varijabla poprimala je izraz I ako je političar na vlasti ponovno izabran, odnosno o ako je smijenjen.
} 


\section{Tablica I.}

Popis empirijskih istraživanja o PBC-u razvijenim zemljama

Autori

Seitz (200o.): II saveznih

pokrajina Zapadne Njemačke, I970.-I996.

\section{Metodologija}

Statička panel analiz

s fiksnim učincima

Pettersson-Lidbom (2000.)

Švedska, 288 jedinica na

lokalnoj razini, I974.-I998.
Dinamička panel analiza,

Anderson-Hsiao

procjenitelj

\section{Varijable}

Primarni proračunski saldo, ukupn

izdaci, kapitalni izdaci, pomoći

središnje države, rashodi za zaposlene,

ukupni prihodi, prihodi od poreza
Galli i Rossi (2002.): II saveznih pokrajina Zapadne Njemačke, I974.-I994.

Rose (2006.): 43 savezne države SAD-a, 1974.-1999.

Alt i Lassen (2006.): I9 OECD zemalja, I990.-1999.

Veiga i Veiga (2006): 278 lokalnih jedinica u Portugalu, I979.-200I.

Schneider (20IO.): savezne pokrajine Zapadne Njemačke, I970.-2003.

Katsimi i Sarantides (2012.): 19 OECD zemalja, 1972.-1999.

Izvor: autor.

\section{Zaključak}

Nema potvrde o stranački svrstanim PBC-ima

U izbornoj godini porezi opadaju i javni izdaci rastu sukladno Rogoffovu modelu, u postizbornoj godini javni izdaci su viši i porez

Statička panel analiza s fiksnim učincima

Dinamička panel analiza,

Arellano-Bondov procjenitelj

Dinamička panel analiza,

Arellano-Bondov

procjenitelj

Dinamička panel analiza

Arellano-Bondov procjenitelj

Statička panel analiza

s fiksnim učincima

Statička panel analiza s fiksnim učincima niži za reizabranu, u odnosu na novu vladu, reizabrana vlada troši manje i oporezuje više u postizbornoj u odnosu na izbornu godinu i izdaci su pozitivno povezani s izbornim uspjehom kad se porezi drže fiksnim

Javni rashodi, prihodi od porez

agregatna stopa rasta BDP-a

Ukupni izdaci, suficit/deficit,

administracija, zdotvrda postojanja oportunističkih PBC, rast javnih izdataka u ceste i socijalne naknade

Proračunski saldo, porezni prihodi, javni izdaci, pomoći od središnje države (per capita) zbornoj godini

Fiskalna ograničenja pojedinih saveznih država sprječavaju pojavu ciklusa u proračunskom saldu

Proračunski saldo (\% BDP-a), indeks fiskalne transparentnost

Fiskalno netransparentnije i politički polariziranije zemlje u izbornom razdoblju bilježe cikluse u proračunskom saldu

Oportunističko ponašanje političara sukladno modelima asimetričnih informacija, porast izdataka u predizbornom razdoblju i promjena u strukturi izdataka u korist kapitalnih izdataka (per capita)

Političari manipuliraju strukturom proračuna uslijed

Stope rasta proračunskog deficita, ukupnih izdataka i socijalnih naknada institucionalnih ograničenja, ali nema ciklusa u proračunskom saldu i ukupnim izdacima

Testiran je model moralnog hazarda, ali statistički značajan je samo ciklus u prihodima (negativna korelacija s izborima)
Proračunski saldo, javni izdaci i prihodi 


\section{TABlica 2.}

Popis empirijskih istraživanja o PBC-u tranzicijskim zemljama i zemljama u razvoju

\section{Autori}

Hallerber i de Souza

(2000.): Io novih članica

EU, 1990.-1999.

Metodologija

Varijable
Analiza vremenskih serija

Proračunski saldo, novčana masa i devizni tečaj

\section{Zaključak}

Proračunski deficit raste za I, $5 \%$ u predizbornom razdoblju ako zemlja ima fiksni tečaj, ako ima fleksibilni devizni tečaj, u predizbornom razdoblju, povećava se novčana masa za o,I4\% BDP-a, ako središnja banka nije neovisna

Ukupni izdaci, socijalne naknade, udio socijalnih naknada, izdaci za obrazovanje, kulturu i

Akhmedov i Zhuravskaya (2004.): Rusija, izbori na lokalnoj razini,

Statička panel analiza s fiksnim učincima i LOGIT obrazovanje, oglašavanje u medijima, udio izdatak za oglašavanje u medijima, izdaci za industriju; ukupni prihodi, prihodi od poreza, omjer ukupnih izdataka i ukupnih prihoda, stope rasta, stope inflacije, razine nadnica

Potvrda Rogoffova modela, oportunistički ciklus u visini i strukturi javnih izdataka u izbornom razdoblju (tekući izdaci se povećavaju), institucionalne varijable i vrijeme smanjuju jačinu ciklusa,

predizborna manipulacija povećava popularnost i vjerojatnost reizbora političara na vlasti

Maurel, (2006.): 25 EU zemalja, Bugarska,

Statička panel analiza Ukupni izdaci i ukupni prihodi, proračunski saldo s fiksnim (\% BDP-a), monetarni agregat M3 I990.-2005.
Klašnja (2008.), 25

Statička panel analiza s fiksnim učincima

avni izdaci i prihodi, proračunski saldo, socijaln transferi i “lokalna javna dobra” (izdaci za tekuća dobra i usluge, kapitalni izdaci i plaće, tj. instrumenti koji mogu biti ciljani užim grupama, bilo geografski bilo društveno) (\% BDP-a)

Vučković (2010.):

Hrvatska, 1995.-2008.

Analiza vremenskih serija

Proračunski prihodi, rashodi i saldo (\% BDP-a)

Schuknecht (2000.): 24 zemlje u razvoju, I973. 1992.

Statička panel analiza s fiksnim učincima

avni izdaci, javni prihodi, proračunski saldo, tekući izdaci, kapitalni izdaci, izdaci za zaposlene postkomunističkih zemalja, 1990.-2006

Porast ukupnih izdataka i proračunskog deficita u izbornoj godini i kod starih i novih članica EU-a

Porast deficita za I,05\% i javnih izdataka za o,82\% u izbornom razdoblju, unutar strukture izdataka porast izdataka za socijalu za o,63\% u izbornom i o, $45 \% \mathrm{u}$ postizbornom razdoblju, u predsjedničkim sustavima i zemljama s većinskim izbornim sustavima, postoje ciklusi u socijalnim transferima, uz istodobne rezove $\mathrm{u}$ poreznim prihodima koji nisu zabilježeni u zemljama parlamentarne demokracije i razmjernim izbornim sustavima

Oportunistički ciklusi na strani državnih rashoda (porast u kvartalu prije i pad u kvartalu nakon izbora)

Porast javnih izdataka u predizbornom razdoblju, uz porast kapitalnih izdataka u odnosu na tekuće izdatke u predizbornom razdoblju

Gonzalez (2002.): Analiza vremenskih Proračunski saldo, ukupni izdaci i prihodi, Meksiko, I957.-I997. serija
Javni izdaci u infrastrukturu i transferi ključna potvrda postojanja oportunistički motiviranih PBC-a 


\section{Autori}

Persson i Tabellin (2002.): 60 zemlja, 1960.-1998.

Khemani (2004.): I4

saveznih država u Indiji,

I960.-1994.

Brender i Drazen (2004.): 68 zemalja, 1960.-200I

Drazen i Eslava (2005.):

Kolumbija (izbori na

lokalnoj razini),

I992.-2000.

Shi i Svensson (2006.):

85 razvijenih i zemalja

u razvoju, 1975.-1995.

\section{Metodologija}

Statička panel analiza s fiksnim učincima

Analiza vremenskih

serija

Statička panel analiza

s fiksnim učincima

Dinamički panel model, GMM procjenitelj

\section{Dinamička panel}

analiza, sistemski

GMM procjenitel

\section{Varijable}

Ukupni izdaci, prihodi, deficit, socijalne naknade

Proračunski saldo, javne investicije, javni prihodi, javni rashodi

Proračunski saldo, ukupni prihodi, ukupni rashodi (\% BDP-a)

Tekući izdaci, kapitalni izdaci, izdaci za financijsku imovinu i otplate zajmova

Proračunski saldo kao udio BDP-a

razdoblju od 2 godine prije izbora $u$ odnosu na omjer saldo/BDP u razdoblju 2 godine prije toga) $i$

BALCH_ey (promjena $u$ omjeru saldo/BDP u izbornoj godini u odnosu na omjer saldo/BDP u prethodnoj godini)

Dinamička panel analiza, sistemski

Naruhiko Sakurai i Menezes-Filho (2OII.):

Brazil, I989.-2005.
Proračunski saldo, ukupni javni izdaci (tekući i kapitalni izdaci), porezni prihodi lokalnih jedinica

\section{Zaključak}

Smanjenje oporezivanja u predizbornom razdoblju neovisno je li demokracija parlamentarnog ili predsjedničkog tipa, ali samo potonja bilježi rezanje potrošnje i porast oporezivanja $u$ postizborno vrijeme

Izborna godina je pozitivno korelirana s investicijama i negativno s pojedinim porezima na potrošnju, nema ciklusa u proračunskom saldu

Rast izdataka i proračunski deficit $\mathrm{u}$ izbornim godinama $\mathrm{u}$ zemljama koje su karakterizirane kao "nove demokracije"

Nema porasta ukupnih izdataka u izbornim godinama, promjen u strukturi, tj. smanjenje tekućih i porast kapitalnih izdataka ali uz porast plaća zaposlenima na neodređeno u javnim službama)

Rast deficita u izbornoj godini za I\%, jači utjecaj primijećen kod zemalja u razvoju (jednako kao i porast javnih izdataka) uslijed utjecaja institucionalnih varijabli i informiranosti birača

Proračunski deficit u izbornom razdoblju ili smanjuje mogućnost reizbora ili nema statistički značajan utjecaj na mogućnost reizbora političara na vlasti

Postojanje oportunističkih i stranački motiviranih ciklusa na lokalnoj razini sukladno Rogoffovom modelu, porast proračunskog deficita (porast tekućih izdataka i smanjenje lokalnih poreznih prihoda) u izbornom razdoblju

Izvor: autor. 


\section{ISTRAŽIVANJE POLITIČKO-PRORAǦUNSKIH GIKLUSA U HRVATSKOJ NA RAZINI GRADOVA}

\section{I. PODAGI}

Model kojim će se empirijski testirati postojanje PBC-a obuhvaća 2I prostornu jedinicu (I9 županijskih središta, Grad Zagreb i Pulu) u razdoblju 2002.-II., kad su održana tri ciklusa parlamentarnih izbora (2003., 2007. i 20II.) i dva ciklusa lokalnih izbora (2005. i 2009.), te su svi rezultati prikazani na gradskoj (lokalnoj) razini. U uzorku se nalaze sva županijska središta i Grad Zagreb, ali umjesto Pazina u Istarskoj županiji odabrana je Pula. Pula je izabrana jer ona predstavlja gospodarsko, financijsko, kulturno, prometno, zdravstveno i obrazovno središte Istarske županije. Izbor županijskih središta unutar 33 hrvatska grada koja su preuzela decentralizirane funkcije, proizlazi iz njihove veličine i jer predstavljaju pokretače trendova $\mathrm{u}$ fiskalnim varijablama na lokalnoj razini. Nadalje, NPE se temelji na Hamiltonovom pristupu političkoj ekonomiji koja naglašava važnost ekonomskih poticaja, ali i političkih ograničenja, u objašnjavanju ekonomskih ishoda. Potonje se ogleda u simboličkoj važnosti obavljanja izvršne vlasti u odabranim gradovima za svaku političku stranku, iz čega slijedi i teorijska pretpostavka da će upravo ta ograničenja znatno utjecati na ekonomske ishode.

U modelu se koriste podaci iz arhive lokalnih proračuna Ministarstva financija, Državnog izbornog povjerenstva i DZS-a. Kao početna godina analize uzeta je 2002. kad je otpočela fiskalna decentralizacija.

U modelu će se koristiti dinamička panel analiza sa zavisnim varijablama preuzetim iz gradskih proračuna. Promatrane zavisne varijable u modelu su:

I) proračunski saldo (\% ukupnih prihoda),

2) ukupni rashodi (\% ukupnih prihoda),

3) rashodi poslovanja (\% ukupnih prihoda),

4) ostali rashodi (\% ukupnih prihoda),

5) rashodi za nabavu nefinancijske imovine (\% ukupnih prihoda),

6) prosječan broj zaposlenih u gradskim tijelima (\% broja stanovnika),

7) prosječan broj zaposlenih kod gradskih korisnika (\% broja stanovnika),

8) rashodi za zaposlene u gradskim tijelima (\% ukupnih prihoda),

9) rashodi za zaposlene kod gradskih korisnika (\% ukupnih prihoda).

Model uključuje i šest binarnih (engl. dummy) varijabli:

I) Izborna godina (poprima vrijednost I ako je riječ o izbornoj godini, u suprotnom je o),

2) Predizborna godina (poprima vrijednost I ako je riječ o predizbornoj godini, u suprotnom je o),

3) Postizborna godina (poprima vrijednost I ako je riječ o postizbornoj godini, u suprotnom je o),

4) Ideološka/stranačka podudarnost /IDEO/ (poprima vrijednost I ako vlast na lokalnoj razini obnašaju predstavnici iste političke opcije kao i na središnjoj, u suprotnom je o),

5) Margina (poprima vrijednost I ako je postotak glasova koje je pobjednik dobio u odnosu na drugoplasiranu stranku manji od 5\%, u suprotnom je o),

6) Kriza (poprima vrijednost I u razdoblju 2009.-II., u suprotnom je o).

Sukladno teorijskim modelima, temeljenim na asimetričnosti informacija, u kojima se pretpostavlja da se izbori održavaju svake dvije godine i u ovom radu kreće se od iste pretpostavke. ${ }^{\text {Io }}$ Pokušat će se

\footnotetext{
${ }^{\text {Io }}$ Odražavanje izbora svake dvije godine slijedi iz pretpostavke o kompetentnosti političara na vlasti koja slijedi strukturu MA(I) procesa, odnosno upravo traje 2 vremenska razdoblja.
} 
empirijski potvrditi da javni izdaci i proračunski deficit rastu u izbornim godinama, odnosno da na gradskoj razini postoji oportunistički ciklus.

Binarna varijabla IDEO testira ideološku/stranačku podudarnost pri čemu se pretpostavlja da se u izbornim godinama $\mathrm{u}$ gradovima $\mathrm{u}$ kojima su na vlasti predstavnici iste političke opcije kao i u središnjoj vlasti povećavaju javni izdaci i smanjuju javni prihodi. Nastavno na Naruhiko Sakurai i Menezes-Filho (20II:233-247) testirano je kako ideološka podudarnost utječe na promatrane fiskalne varijable i u kojoj mjeri se dobiveni rezultati razlikuju od onih koje su autori dobili na primjeru lokalnih jedinica u Brazilu.

Sukladno Brender i Drazen (2009:2203-2220) kao kontrolne varijable koristimo BDP per capita i BDP jaz ${ }^{\text {II }}$ koji služi kao dodatna kontrola poslovnog ciklusa i jer prihodna strana proračuna ne zavisi u potpunosti od gradskih vlasti, već i o središnjem proračunu kroz udjele u zajedničkim porezima. Uz BDP per capita i BDP jaz, u kontrolne varijable dodajemo i broj stanovnika sukladno Pettersson Lidbom (2000:I-26).

\subsection{Metodologija}

Kao metoda istraživanja, dinamička panel analiza, nalazi primjenu u ekonomskim istraživanjima $u$ kojima sadašnja vrijednost varijable, npr. ukupni rashodi proračuna, zavisi o prethodnim vrijednostima te iste varijable (Baltagi, 2008:I35). Kako autokorelacija, odnosno situacija u kojoj greške relacije u razdoblju $t$ utječu barem na greške relacije u razdoblju $t+\mathrm{I}$, nije uključena u pretpostavke statičkih panel modela, optimalan izbor predstavlja dinamički panel. U suprotnom, procijenjeni parametri bit će konzistentni, ali neefikasni, a standardna greška procijenjenih parametara bit će pristrana (Škrabić, 2009:28). Prednost dinamičke panel analize ogleda se i u njenoj široj ekonomskoj primjeni. Korištenje zavisne varijable s jednim ili više pomaka, neovisno od toga jesu li procijenjeni koeficijenti od izravnog interesa, bitno utječe na konzistentnu procjenu ostalih parametara u modelu (Bond, 2002).

Dinamički panel model, koji sadrži zavisnu varijablu s $t$ - I pomakom, te $K$ nezavisnih varijabli $x_{i t k}, k=1, \ldots K$, zapisuje se kao:

$$
y_{i t}=\mu+\gamma y_{i, t-1}+\beta_{1} x_{i t 1}+\beta_{2} x_{i t 2}+\beta_{K} x_{i t K}+\alpha_{i}+\varepsilon_{i t}, i=1, \ldots N, t=1, \ldots T,
$$

gdje $N$ označava broj jedinica promatranja, $T$ broj razdoblja, a $x_{i t k}, k=1, \ldots K$ označava vrijednost $k$-te nezavisne varijable, $i$-te jedinice promatranja u razdoblju $t$. Parametar $\alpha$ je slučajni ili fiksni efekt, a $\beta_{1}, \ldots \beta_{K}$ su parametri egzogenih varijabli koje treba procijeniti u modelu. Pretpostavlja da su greške relacije $\varepsilon_{i t}$ nezavisno i identično distribuirane slučajne varijable sa sredinom o i varijancom $\sigma_{\varepsilon}^{2}$.

Uvođenje zavisne varijable s pomakom rezultira koreliranosti između zavisne varijable s pomakom $y_{i, t-1}$ i $\alpha_{i}$. Kada bi se navedeni model procijenio metodom najmanjih kvadrata, OLS procjenitelji parametara modela bili bi pristrani i nekonzistentni, čak i u slučaju kad su $\varepsilon_{i t}$ međusobno nekorelirane, slučajne varijable. Arellano i Bond (1991:277-297) predlažu korištenje generalizirane metode momenata (engl. generalized method of moments, GMM) kako bi se procijenili parametri modela. ${ }^{12}$ Obzirom na to, prva diferencija jednadžbe (I) glasi:

\footnotetext{
${ }^{\text {II }}$ BDP jaz je izračunat uz pomoć Hodrick-Prescottovog filtera (l=IOo) u programu EViews 7.

${ }^{12}$ Arrelano-Bondov procjenitelj optimalan je u analizi panel podataka koji su karakterizirani velikim $\mathrm{N}$ (brojem jedinica promatranja) i malim T (brojem razdoblja), što je slučaj i u ovom radu.
} 


$$
\begin{gathered}
y_{i t}-y_{i, t-1}=\gamma\left(y_{i, t-1}-y_{i, t-2}\right)+\beta_{1}\left(x_{i t 1}-x_{i, t-1,1}\right)+\beta_{2}\left(x_{i t 2}-x_{i, t-1,2}\right)+\beta_{K}\left(x_{i t K}-\right. \\
\left.x_{i, t-1, K}\right)+\left(\varepsilon_{i t}-\varepsilon_{i, t-1}\right) ; i=1, \ldots N, t=1, \ldots T .
\end{gathered}
$$

Kako bi procjenitelj parametra $\gamma$ bio konzistentan u dinamički panel model moramo uključiti dodatne instrumente. Valjane instrumente za $\left(y_{i, t-1}-y_{i, t-2}\right)$ predstavljaju zavisne varijable s pomakom u razinama $\left(y_{i 1}, y_{i 2}, \ldots, y_{i, t-2}\right)$ koji omogućavaju iskorištavanje dodatnih uvjeta na momente. Uvođenjem instrumenata za nezavisne varijable, GMM procedura omogućava i rješavanje problema endogenosti varijabli i povratne kauzalnosti. Valjane instrumente za vrijednosti nezavisne varijable $\mathrm{u}$ prvim diferencijama $\left(x_{i, t-1, k}-x_{i, t-2, k}\right), k=1,2, \ldots, K$ predstavljaju nezavisne varijable s pomakom u razinama $\left(x_{i 1 k}, x_{i 2 k}, \ldots, x_{i, t-2, k}\right), k=1,2, \ldots, K$.

Valjanost instrumenata koji se odabiru za procjenu dinamičkog panel modela testira Sarganovim testom. Prihvaćanje nulte hipoteze testa - da su odabrane instrumentalne varijable nekorelirane s rezidualima - upućuje da su svi uvjeti na momente zadovoljeni i da se svi navedeni instrumenti prihvaćaju. Time je potvrđeno da je dinamički panel model adekvatno specificiran. Arellano i Bond (I991:282) razvili su dva dodatna dijagnostička testa o autokorelaciji među prvim diferencijama rezidualnih odstupanja: $m_{1}$ i $m_{2}$. Postojanje autokorelacije drugog ili višeg reda upućuje na probleme pri specifikaciji modela. Pokazuje da neki od uvjeta na momente nisu zadovoljeni i da su procjene parametara nekonzistentne.

Prednosti korištenja Arellano-Bondov GMM procjenitelja $u$ dva koraka ogledaju se $u$ tome jer procjenitelj $\mathrm{u}$ jednom koraku pretpostavlja nezavisnost i identično distribuirane greške relacije $\varepsilon_{i t}$. Procjenitelj u dva koraka ublažava pretpostavku o nezavisnosti i homoskedastičnosti koristeći reziduale dobivene procjenom Arellano-Bondov GMM procjenitelja $\mathrm{u}$ jednom koraku kako bi konstruirao konzistentnu procjenu matrice varijanci i kovarijanci. Dakle, u slučaju kad su $\varepsilon_{i t}$ heteroskedastične, Arellano-Bondov GMM procjenitelj u dva koraka je efikasniji (Višić i Škrabić Perić, 2OII:I78).

Prilikom interpretacije modela, posebna pažnja, posvećena je binarnim nezavisnim varijablama. Odnosno, promatraju se parametri egzogenih varijabli $\beta_{1}, \ldots \beta_{K}$ koji se procjenjuju u modelu. U prvom koraku, zanima nas jesu li statistički značajni i na kojim razinama značajnosti, a u drugom koraku kojeg predznaka im je koeficijent, to jest odgovara li predznak teorijskim postavkama PPC modela.

\subsection{EMPIRIJSKI REZULTATI}

Dinamički panel model koji se koristi u analizi dan je sljedećom jednadžbom:

$$
\begin{gathered}
B V_{i t}=\alpha+\gamma B V_{i, t-1}+\beta_{1} B D P_{-} P C_{i t}+\beta_{2} B D P_{-} J A Z_{i t}+\beta_{3} B R_{-} S T A N_{i t}+\beta_{4} I D E O_{i t}+ \\
\beta_{5} I Z B_{-} G O D_{i t}+\beta_{5} K R I Z A_{i t}+\beta_{5} M A R G I N A_{i t}+\varepsilon_{i t},
\end{gathered}
$$

gdje je zavisna varijabla $B V_{i t}$ jedna od navedenih devet proračunskih varijabli, a $B V_{i, t-1}$ vrijednost zavisne varijable u prethodnom razdoblju. Kontrolne varijable su: $B D P_{-} P C_{i t}, B D P_{-} J A Z_{i t}$ i $B R_{-} S T A N_{i t}$, dok su binarne varijable $I D E O_{i t}$ i $I Z B_{-} G O D_{i t}$ pomoću kojih ćemo pokušati utvrditi postojanje ideološke podudarnosti i oportunističkih ciklusa. Uz binarnu varijablu $I Z B_{-} G O D_{i t} \mathrm{u}$ poduzorcima u kojima se promatraju posebno lokalni i parlamentarni izbori, dodali smo i binarne varijable $I Z B_{-} G O D(-1)_{i t}$ za predizbornu godinu i $I Z B_{-} G O D(+1)_{i t}$ za izbornu godinu. U procijenjeni model uključene su i binarne varijable $K R I Z A_{i t}$ i $M A R G I N A_{i t}$. 
U radu se procjenjuje dvadeset i sedam modela, a za procjenu svakog od modela koristi se GMM Arellano-Bondov procjenitelj u dva koraka. Svi izračuni napravljeni su u statističkom programu Stata/SE II.

Deskriptivna analiza nalazi se u prilogu rada (ispis AI) zajedno s korelacijskom matricom (ispis A2). Na razini značajnosti od $5 \%$ vidimo da nezavisne varijable nisu međusobno snažno korelirane, što bi trebalo značiti da $\mathrm{u}$ procijenjenim modelima nema problema multikolinearnosti. Rezultati ekonometrijske ocjene modela postojanja PBC-a prikazani su u tablicama 4-6.

U strukturi ukupnih prihoda gradova prevladavaju porezni prihodi, a u poreznim prihodima zajednički porezi (porez na dohodak i porez na promet nekretnina) što onemogućava poreznu autonomiju gradova. ${ }^{13}$ Radovi Bajo i Jurlina Alibegović (2008.) i Rogić Lugarić (20Io.) ukazuju na navedeno pa prihodovna strana proračuna nije analizirana i sve ostale proračunske varijable prikazane su kao udio ukupnih prihoda. Preostale dvije varijable - prosječni broj zaposlenih u gradskim tijelima i kod korisnika - izražene su u postotku ukupnog broja stanovnika u odabranom gradu u promatranoj godini.

Rezultati iz tablica 3-5 upućuju da su zadovoljena sva tri dijagnostička testa valjanosti procijenjenih dinamičkih modela. Na temelju Sarganovog testa možemo zaključiti da su korišteni instrumenti dobro odabrani i odbacuje se hipoteza o nepostojanju korelacije reziduala i instrumenata. Osnovna pretpostavka dinamičkog panel modela i Arellano-Bondov procjenitelja da ne postoji autokorelacija grešaka relacije prvog i drugog reda među prvim diferencijama reziduala, odbacuje se tek u slučaju autokorelacije drugog reda i to samo u modelu s ostalim rashodima i modelu sa zaposlenima kod korisnika u tablici 3 na razini značajnosti od Io\%, odnosno u modelu s rashodima poslovanja i ostalim rashodima u tablici 4 i tablici 5 na razini značajnosti od također Io\%.

Rezultati dinamičke panel analize (tablica 3) upućuju na odbijanje hipoteze o postojanju PBC-a na odabranom uzorku u promatranom razdoblju. U modelu sa saldom i u modelu s ukupnim rashodima, binarna varijabla - izborna godina - je statistički značajna, ali koeficijent ima predznak suprotan od očekivanog. Odnosno, u izbornim godinama proračunski saldo se, u prosjeku, poveća za I,9\% ukupnih prihoda, dok se ukupni rashodi, u prosjeku, smanje za 2,8\% ukupnih prihoda.

\footnotetext{
${ }^{13} \mathrm{U}$ odabranom uzorku gradova, udio poreznih u ukupnim prihodima iznosi 64-68\% u promatranom razdoblju.
} 


\section{TABlica 3.}

Rezultati dinamičke panel analize: parlamentarni i lokalni izbori zajedno

\begin{tabular}{|c|c|c|c|c|c|c|c|c|c|}
\hline & $\begin{array}{l}\text { Saldo } \\
\text { (SAL) }\end{array}$ & $\begin{array}{l}\text { Ukupni } \\
\text { rashodi } \\
\text { (UR) }\end{array}$ & $\begin{array}{c}\text { Rashodi } \\
\text { poslovanja } \\
\text { (TC) }\end{array}$ & $\begin{array}{c}\text { Ostali } \\
\text { rashodi } \\
\text { (TC_OST) }\end{array}$ & $\begin{array}{c}\text { Rashodi za } \\
\text { nabavu } \\
\text { nefinancijske } \\
\text { imovine }(\text { RNFI) }\end{array}$ & $\begin{array}{l}\text { Zaposleni u } \\
\text { tijelima } \\
(\text { ZPT })\end{array}$ & $\begin{array}{l}\text { Zaposleni kod } \\
\text { korisnika } \\
\text { (ZPK) }\end{array}$ & $\begin{array}{c}\text { Rashodi za } \\
\text { zaposlene u } \\
\text { tijelima (RZT) }\end{array}$ & $\begin{array}{c}\text { Rashodi za } \\
\text { zaposlene kod } \\
\text { korisnika (RZK) }\end{array}$ \\
\hline Zavisna varijabla & $\begin{array}{l}-, 035 \mathrm{I} 355 \\
(, \mathrm{II} 23 \mathrm{O} 43)\end{array}$ & $\begin{array}{l}\text {,I73I79*** } \\
(, I O 26024)\end{array}$ & $\begin{array}{c}-, 318688^{*} \\
(, \mathrm{IO} 88477)\end{array}$ & $\begin{array}{c}, 0704949^{* *} \\
(, 0355532)\end{array}$ & $\begin{array}{l}, 2981087^{*} \\
\text { (,o821392) }\end{array}$ & $\begin{array}{l}-, I 47029 I^{*} \\
(, 0242799)\end{array}$ & $\begin{array}{l}-, 2935822^{*} \\
(, 0747549)\end{array}$ & $\begin{array}{l}, 2167674^{*} \\
(, 02405)\end{array}$ & $\begin{array}{l}\text {,038I303 } \\
\text { (,o6488I7) }\end{array}$ \\
\hline BDP jaz & $\begin{array}{l}2,29 \mathrm{e}-09^{*} \\
(4,57 \mathrm{e}-\mathrm{IO})\end{array}$ & $\begin{array}{l}-3,29 \mathrm{e}-09^{*} \\
(6,22 \mathrm{e}-\mathrm{IO})\end{array}$ & $\begin{array}{c}7,63 \mathrm{e}-\mathrm{IO} \mathrm{O}^{* * *} \\
(4, \mathrm{IOe}-\mathrm{IO})\end{array}$ & $\begin{array}{l}-5, \mathrm{I} 8 \mathrm{e}-\mathrm{IO} * \\
(\mathrm{I}, 98 \mathrm{e}-\mathrm{IO})\end{array}$ & $\begin{array}{l}-2,26 \mathrm{e}-09^{*} \\
(4,80 \mathrm{O}-\mathrm{IO})\end{array}$ & $\begin{array}{l}-6,2 \mathrm{Oe}-\mathrm{II}^{*} \\
(2,7 \mathrm{Ie}-\mathrm{I} 2)\end{array}$ & $\begin{array}{l}-\mathrm{I}, 63 \mathrm{e}-\mathrm{IO} * \\
(6,25 \mathrm{e}-\mathrm{I} 2)\end{array}$ & $\begin{array}{c}\text { 6,o2e-II } \\
(8,06 e-I I)\end{array}$ & $\begin{array}{c}3,58 \mathrm{e}-\mathrm{IO}{ }^{* *} \\
(\mathrm{I}, \mathrm{I} 3 \mathrm{e}-\mathrm{IO})\end{array}$ \\
\hline$B D P p c$ & $\begin{array}{l}4,52 \mathrm{e}-\mathrm{o6} * \\
(\mathrm{I}, 2 \mathrm{Oe}-06)\end{array}$ & $\begin{array}{c}-7,46 \mathrm{e}-06^{*} \\
(\mathrm{I}, 54 \mathrm{e}-06)\end{array}$ & $\begin{array}{c}-2,08 \mathrm{e}-06^{* *} \\
(8,08 \mathrm{e}-07)\end{array}$ & $\begin{array}{l}-3,37 \mathrm{e}-07 \\
(4,23 \mathrm{e}-07)\end{array}$ & $\begin{array}{l}-4,83 \mathrm{e}-06^{*} \\
(9,6 \mathrm{oe}-07)\end{array}$ & $\begin{array}{l}-9,60 \mathrm{o}-08^{*} \\
(4,06 \mathrm{e}-09)\end{array}$ & $\begin{array}{l}-2,39 \mathrm{e}-07^{*} \\
(\mathrm{I}, 6 \mathrm{oe}-08)\end{array}$ & $\begin{array}{c}-\mathrm{I}, \mathrm{III}-\mathrm{O} 7 \\
(2,23 \mathrm{e}-\mathrm{O} 7)\end{array}$ & $\begin{array}{l}-4,53 \mathrm{e}-08 \\
(\mathrm{I}, 9 \mathrm{Ie}-07)\end{array}$ \\
\hline Broj stanovnika & $\begin{array}{l}\text { 5,02e-o6 } \\
(3,90 e-06)\end{array}$ & $\begin{array}{c}-\mathrm{I}, \mathrm{Ooe}-05^{* *} \\
(4,00 \mathrm{e}-06)\end{array}$ & $\begin{array}{c}4,40 \mathrm{e}-07 \\
(2,22 \mathrm{e}-06)\end{array}$ & $\begin{array}{c}\text { 3,23e-o6*** } \\
(\mathrm{I}, 89 \mathrm{e}-06)\end{array}$ & $\begin{array}{c}-, \text {,oooolo2* } \\
(3,23 \mathrm{e}-06)\end{array}$ & $\begin{array}{l}\mathrm{I}, 34 \mathrm{e}-\mathrm{O} 7^{*} \\
(2,82 \mathrm{e}-\mathrm{O} 8)\end{array}$ & $\begin{array}{l}5,88 \mathrm{e}-07^{*} \\
(\mathrm{I}, 28 \mathrm{e}-07)\end{array}$ & $\begin{array}{l}-3,03 \mathrm{e}-07 \\
(3,7 \mathrm{Ie}-07)\end{array}$ & $\begin{array}{c}-8, \mathrm{IIe}-07 \\
(\mathrm{I}, 23 \mathrm{e}-06)\end{array}$ \\
\hline IDEO & $\begin{array}{l}\text {,oI98274 } \\
\text { (,oI287I3) }\end{array}$ & $\begin{array}{c}-, 0460624^{*} \\
(, 008964)\end{array}$ & $\begin{array}{l}, 0040866 \\
(, 0068872)\end{array}$ & $\begin{array}{l}\text {,OII4I79** } \\
\text { (,oo4935) }\end{array}$ & $\begin{array}{c}-, 0253755^{* *} \\
(, 0098597)\end{array}$ & $\begin{array}{c}-8,69 \mathrm{e}-06 \\
(, 0000835)\end{array}$ & $\begin{array}{l}-, \text { oool955 } \\
\text { (,oool803) }\end{array}$ & $\begin{array}{l}-, 0004434 \\
(, 0030327)\end{array}$ & $\begin{array}{l}-, 0055763 \\
(, 0062833)\end{array}$ \\
\hline Izborna godina & $\begin{array}{l}\text {,ol86727* } \\
\text { (,oO54602) }\end{array}$ & $\begin{array}{l}\text {-,o2789II* } \\
\text { (,o079538) }\end{array}$ & $\begin{array}{l}-, 0093125 \\
(, 0058173)\end{array}$ & $\begin{array}{l}\text {,oog3686* } \\
\text { (,oo2925) }\end{array}$ & $\begin{array}{c}-, \mathrm{OI} 36 \mathrm{I} 25^{* * *} \\
(, 0077923)\end{array}$ & $\begin{array}{l}-,, 0005339^{*} \\
(, 000027)\end{array}$ & $\begin{array}{l}-, \text { OOI467* } \\
\text { (,ooolO72) }\end{array}$ & $\begin{array}{l}\text {,oo27968* } \\
\text { (,ooo9586) }\end{array}$ & $\begin{array}{l}-, 0056405^{*} \\
\text { (,ooo7756) }\end{array}$ \\
\hline Kriza & $\begin{array}{l}-, 0854314^{*} \\
(, 0132365)\end{array}$ & $\begin{array}{l}\text {,IOO4I9* } \\
\text { (,oI55893) }\end{array}$ & $\begin{array}{l}\text {,o846415\% } \\
\text { (,oI28869) }\end{array}$ & $\begin{array}{l}\text {,oolio65 } \\
\text { (,oo61255) }\end{array}$ & $\begin{array}{l}\text {,oo26573 } \\
\text { (,oI6674I) }\end{array}$ & $\begin{array}{l}\text {,ool7613* } \\
(, 0000767)\end{array}$ & $\begin{array}{l}\text {,oo39293* } \\
\text { (,oooI80I) }\end{array}$ & $\begin{array}{l}\text {,OII7726* } \\
\text { (,oO30927) }\end{array}$ & $\begin{array}{l}\text {,oigo663* } \\
\text { (,oo36976) }\end{array}$ \\
\hline Margina & $\begin{array}{l}\text {,ooo8I64 } \\
\text { (,olI5389) }\end{array}$ & $\begin{array}{l}\text {,OI384I5 } \\
\text { (,oI655I5) }\end{array}$ & $\begin{array}{c}-, \text { OI54585 } \\
(, 0093059)\end{array}$ & $\begin{array}{l}-, 0025566 \\
(, 0042739)\end{array}$ & $\begin{array}{l}\text {,O3O7741** } \\
(, 014926)\end{array}$ & $\begin{array}{l}\text {,0003067* } \\
(, 0000482)\end{array}$ & $\begin{array}{l}, 0006735^{*} \\
(, 0002458)\end{array}$ & $\begin{array}{l}-, 0038908 \\
(, 0025652)\end{array}$ & $\begin{array}{l}-, 0061244^{* *} \\
(, 0027036)\end{array}$ \\
\hline _cons & $\begin{array}{l}-, 7211676^{* *} \\
(, 3229327)\end{array}$ & $\begin{array}{l}2,338167^{*} \\
(, 3242469)\end{array}$ & $\begin{array}{l}\text { I,060523* } \\
(, 2795429)\end{array}$ & $\begin{array}{l}-, \mathrm{I} 524 \mathrm{IO} 2 \\
(, \mathrm{I} 7 \mathrm{O} \mathrm{I} \mathrm{I} 97)\end{array}$ & $\begin{array}{l}\text { I,672986* } \\
(, 2824686)\end{array}$ & $\begin{array}{l}-, 0029356 \\
\text { (,oO3O242) }\end{array}$ & $\begin{array}{l}-, 0354755^{* *} \\
\text { (,o150286) }\end{array}$ & $\begin{array}{l}\text {,o85889** } \\
\text { (,o4II293) }\end{array}$ & $\begin{array}{l}, 2049066 \\
(, \mathrm{I} 28 \mathrm{IO} 29)\end{array}$ \\
\hline $\mathrm{N}$ & 168 & 168 & 168 & 168 & 168 & 168 & 168 & I68 & 168 \\
\hline $\begin{array}{l}\text { Sargan test } \\
\text { (p-vrijednost) }\end{array}$ & o,9996 & I,OOOO & o,9995 & o,9998 & o,9997 & o,9955 & o,9904 & o,9988 & I,OOOO \\
\hline $\mathrm{AR}(\mathrm{I})$ test & O,OI54 & 0,0060 & 0,1256 & 0,0403 & 0,0055 & O,OOOI & 0,0089 & 0,0387 & 0,2438 \\
\hline $\mathrm{AR}(2)$ test & 0,8070 & 0,8419 & O,IOOO & 0,0988 & 0,3446 & 0,7807 & 0,0694 & 0,5722 & 0,4396 \\
\hline
\end{tabular}

Napomena: *, **, *** označava statističku značajnost na razini od I\%, 5\% i 1о\%. Standardne pogreške su u zagradama.

Izvor: izračun autora. 


\section{GRAFIKON I.}

Proračunski saldo, rashodi poslovanja i rashodi za nabavu nefinancijske imovine (u mlrd. kuna)

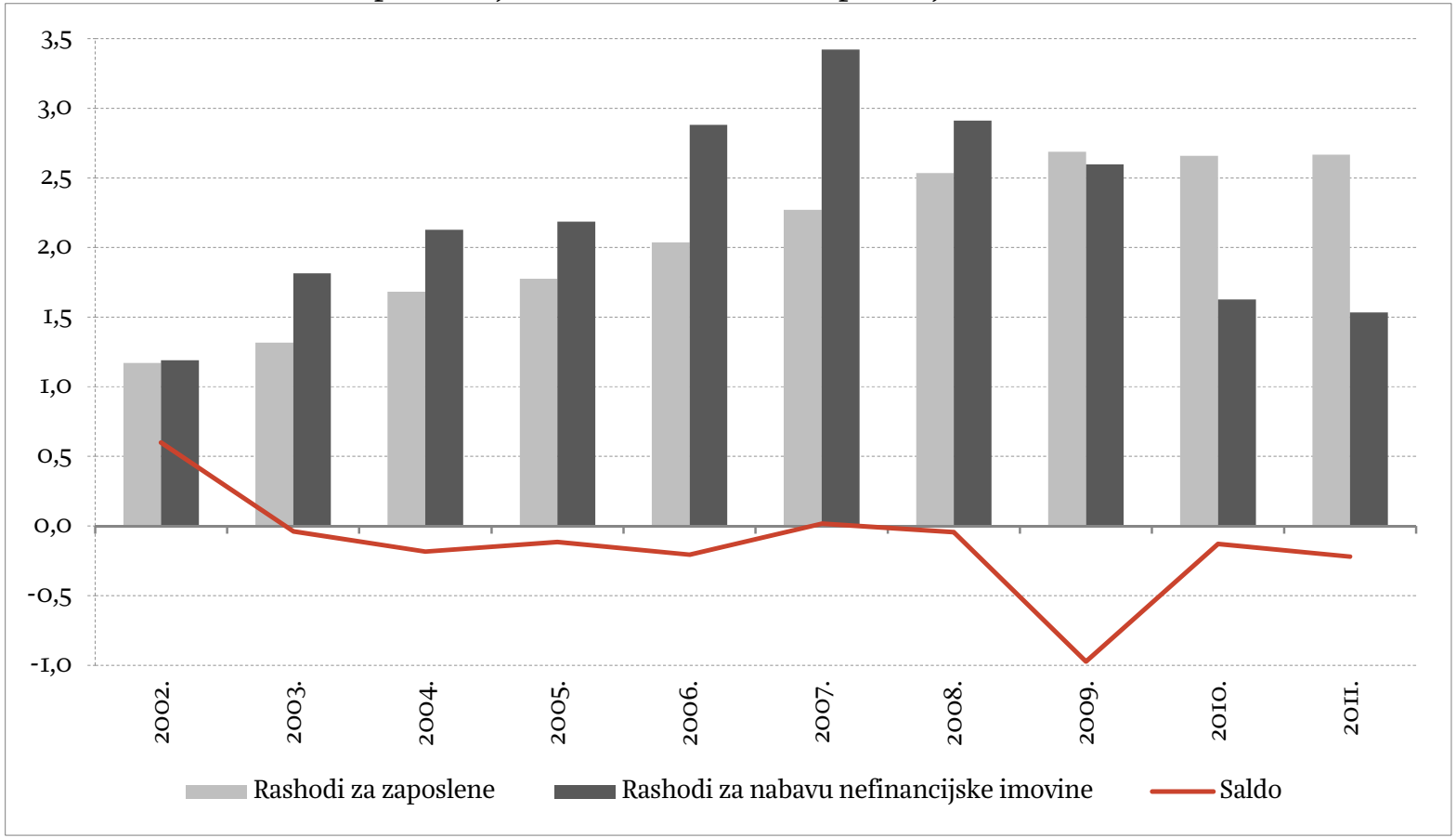

Izvor: Izračun autora.

Temeljem rezultata istraživanja, odabrane hrvatske gradove ne možemo svrstati u "stare demokracije”, budući da su Brender i Drazen (2004.) za tu skupinu dobili koeficijent koji ima negativni predznak, ali koji je statistički neznačajan. Sukladno Rose (2006.) rezultati upućuju da je oportunistička manipulacija fiskalnim instrumentima određena institucionalnim kontekstom unutar kojeg se odvija proračunski proces. Ograničenja koja postoje za zaduživanje hrvatskih gradova, a koja navode Bajo i Jurlina Alibegović (2008.) i Primorac (20II.), predstavljaju potvrdu toga. Stoga ovi rezultati upućuju da proračunska ograničenja u zaduživanju gradova ${ }^{\mathrm{I}}$ rezultiraju smanjenjem oportunistički motiviranih PBC-a. ${ }^{15}$ Implikacije tog zaključka na državnoj razini potencijalno bi mogle značiti i smanjenje ukupnih rashoda u izbornim godinama za što se zalaže i konstitucionalna politička ekonomija. Vučković (2OII.) na razini konsolidirane središnje države dokazuje da je jedina statistički značajna varijabla, $s$ očekivanim teorijskim predznakom, $\mathrm{u}$ izbornoj godini upravo varijabla ukupni rashodi. To otvara i niz pitanja veznih uz provođenje ekonomske politike unutar takvog konteksta, od kojih je najznačajnije ograničeno korištenje kontracikličke fiskalne politike. Deskriptivna analiza (grafikon I) na uzorku hrvatskih gradova pokazuje da su se rashodi za nabavu nefinancijske imovine (RNFI) smanjivali od 2008. dok su rashodi za zaposlene rasli ili ostali na približno istoj razini. Odnosno, fiskalna politika na lokalnoj razini se ne koristi u kontracikličke svrhe, već stvara state capture i (pre)veliki utjecaj birokracije.

Nadalje, provedena ekonometrijska analiza potvrđuje da se u izbornim godinama smanjuju rashodi za nabavu nefinancijske imovine (u prosjeku za I,4\% ukupnih prihoda), dok se istodobno povećavaju stavke ostali rashodi (u prosjeku za o,9\% ukupnih prihoda) i rashodi za zaposlene u tijelima (u prosjeku za $0,3 \%$ ukupnih prihoda). Iz toga slijedi da manipulacija strukturom ukupnih rashoda služi

\footnotetext{
${ }^{14}$ Vlada i Ministarstvo financija ograničavaju zaduživanje lokalnih jedinica do 2,3\% ukupno ostvarenih prihoda poslovanja svih lokalnih jedinica (Bajo i Jurlina Alibegović, 2008:I35).

${ }^{15}$ Primorac (20II:46I) navodi da se gradovi mogu zaduživati preko komunalnih poduzeća koja se nalaze u njihovom vlasništvu i na taj način zaobići institucionalna ograničenja navedena u Zakonu o proračunu i zakonima o izvršavanju državnog proračuna.
} 
političarima na vlasti kao druga najbolja strategija u izbornim godinama. Sukladno nalazima Schneider (20Io.) pronalazimo da političari na vlasti, uslijed institucionalnih ograničenja, posežu upravo za tom, jedinom preostalom, fiskalnom strategijom.

Deskriptivna statistika odnosa proračunskog salda i rashoda za zaposlene u tijelima prikazana na grafikonu 2 ukazuje da su, bez obzira na kretanje proračunskog salda, rashodi kontinuirano rasli do 2009. Rashodi za zaposlene u 20IO. opadaju, nakon čega u 2OII. održavanja posljednjih parlamentarnih izbora, opet rastu. U čitavom tom razdoblju proračunski saldo analiziranih gradova bio je u suficitu samo 2002. i 2007. To upućuje ne samo na fiskalnu neodgovornost političkih elita na lokalnoj razini, već i na polit-ekonomske probleme u planiranju i provođenju proračunske politike i na očigledno rentijersko ponašanje lokalne birokracije. Pritom političari na vlasti očigledno računaju da će time osigurati dodatne glasove. Tullock (1987:IO43) navodi empirijska istraživanja, koja potvrđuju navedeno.

\section{GRAFIKON 2.}

Proračunski saldo i rashodi za zaposlene u tijelima i kod korisnika (u mlrd. kuna)

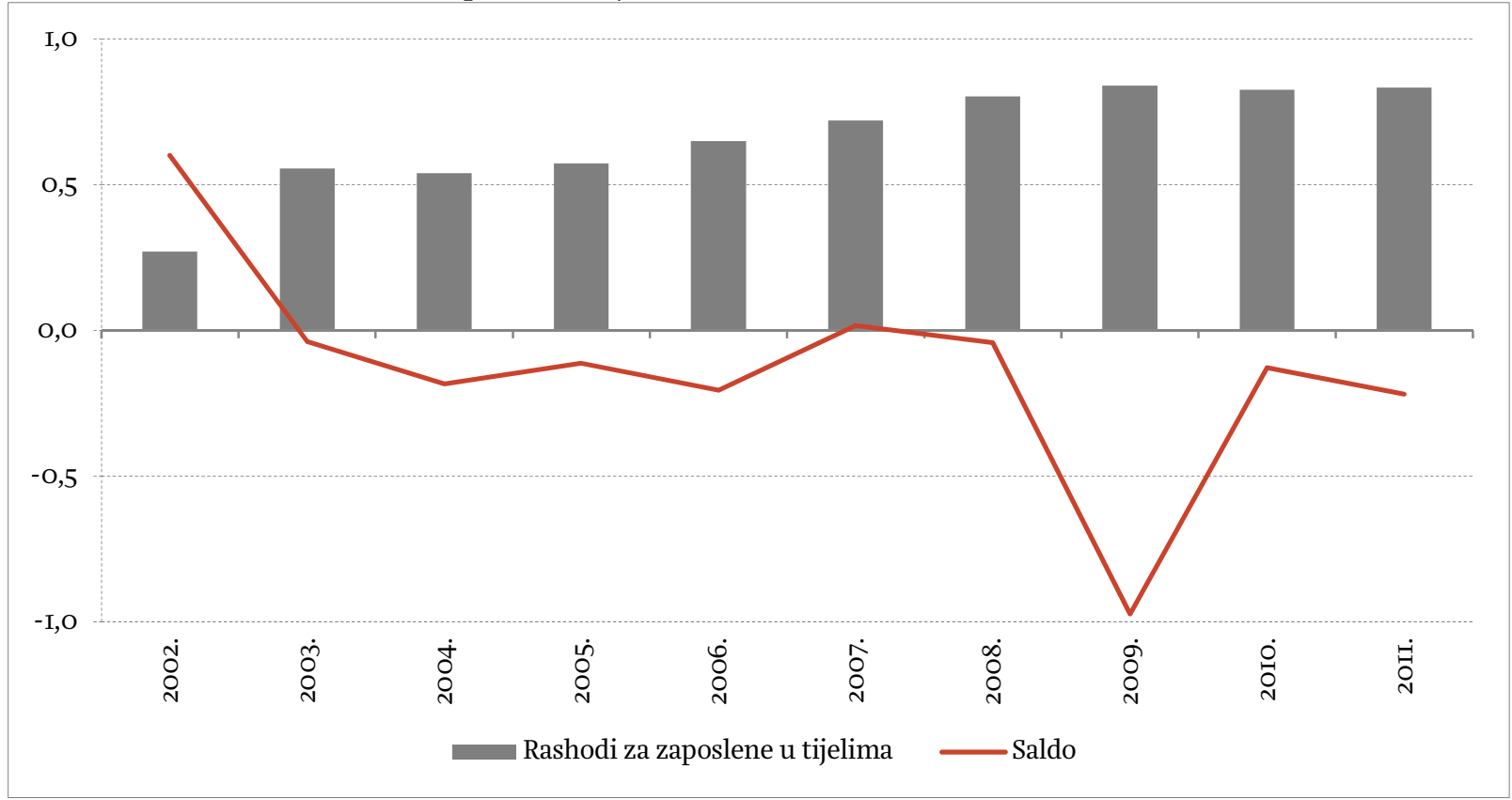

Izvor: Izračun autora.

Ekonometrijska analiza pokazuje da dok prosječan broj zaposlenih pada u izbornim godinama i u gradskim tijelima (u prosjeku za o,o53\% broja stanovnika) i kod korisnika (u prosjeku za o,I5\% broja stanovnika), rashodi za zaposlene $\mathrm{u}$ tijelima u izbornim godinama u prosjeku rastu i to za o,27\% ukupnih prihoda. Dodatno, pad rashoda za zaposlene kod korisnika - u prosjeku za o,56\% ukupnih prihoda - uz istodoban porast rashoda za zaposlene u tijelima može se povezati s činjenicom da političari na vlasti provode distribucijske politike, sukladno Lowijevoj tipologiji javnih politika (Petak, 2008:455). Naime, porast rashoda za plaće zaposlenih u tijelima očigledno se financira smanjenjem drugih proračunskih stavki. Na taj se način zaposleni u upravljačkom i političkom sektoru štite i nagrađuju, dok se plaće zaposlenih kod korisnika, koje podrazumijevaju profesionalna znanja, jer je riječ o poslovima u sektoru obrazovanja i kulture, smanjuju. Navedeno se poklapa i s nalazima istraživanja Rogić Lugarić (20I2:II6-II7) u situaciji u kojoj se događa proračunski suficit u gradovima. Višak prihoda u proračunu može se upotrijebiti za smanjivanje postojećeg oporezivanja ili za smanjenje duga ili se može prenijeti u sljedeću godinu i rasporediti za određene, većinom tekuće namjene. Takva odluka o raspodjeli je distribucijska i politička. Drazen i Eslava (2005:22) također pronalaze statistički 
značajan porast rashoda za zaposlene na neodređeno, koji povezuju s raširenim vjerovanjem po kojem političari u Kolumbiji trguju radnim mjestima u zamjenu za političku potporu i glas na izborima.

Stranačka podudarnost političara na vlasti na gradskoj i državnoj razini, odnosno varijabla IDEO, statistički je značajna samo u slučaju varijabli: ukupni rashodi, ostali rashodi i rashodi za nabavu nefinancijske imovine. Sve tri navedene varijable statistički su značajne i kad se promatraju posebno ishodi parlamentarnih i lokalnih izbora. Pritom su im predznaci i procijenjeni koeficijenti jednaki. Negativan predznak za varijable ukupni rashodi (smanjenje, u prosjeku, za 4,6\% ukupnih prihoda) i rashodi za nabavu nefinancijske imovine (smanjenje, u prosjeku, za 2,53\% ukupnih prihoda) upućuje na sljedeća dva zaključka. Prvi, kretanje tih varijabli suprotno je od očekivanog teorijskog smjera i rezultati se ne poklapaju s rezultatima istraživanja Naruhiko Sakurai i Menezes-Filho (20II.) na primjeru lokalnih izbora u Brazilu. Drugo, dobiveni predznaci koeficijenata jednaki su za binarnu varijablu izborna godina i IDEO, što upućuje da stranačka podudarnost očito nema ulogu prilikom alokacije/distribucije proračunskih sredstava. Nastavno na Jurlina Alibegović i dr. (20Io.) vidimo da je povezanost središnje i lokalnih jedinica vlasti prvenstveno određena preko decentraliziranih funkcija koje lokalne jedinice preuzimaju za sebe i pripadajućeg dijela javnih prihoda koje su im pritom dodijeljene. Odnosno, preko modela fiskalnog izravnanja za koji Bajo i Bronić (2008.) na uzorku 5\% populacije općina i gradova, te Bronić (2010.) na uzorku županija ocjenjuju neuspješnim, ali u identifikaciji razloga ne pronalaze niti jedan koji je vezan uz stranačku pripadnost.

Kako bi se pokušale uhvatiti potencijalne koristi od predizbornih manipulacija u situaciji neizvjesnog ishoda izbora u model je dodana i binarna varijabla margina. Rezultati ponovno upućuju da će se političari na vlasti u tom slučaju okrenuti drugoj najboljoj strategiji. Restrukturiranjem stavki na rashodnoj strani proračuna, $u$ izbornoj godini, političari na vlasti će u prosjeku smanjiti rashode poslovanja za I,5\% ukupnih prihoda i istodobno povećati rashode za nabavu nefinancijske imovine za 3,I\% ukupnih prihoda. Odnosno, birači u tim gradovima mogu očekivati povećanje kapitalnih investicija, uz istodobno smanjenje tekućih izdataka u proračunu, bez ciklusa u proračunskom saldu. Khemani (2004.) dobiva identične rezultate za izbore u I4 saveznih pokrajina $u$ Indiji. Također, $u$ promatranom uzorku vidimo da će se političar na vlasti okrenuti i dodatnom zapošljavanju u izbornoj godini. U prosjeku broj zaposlenih u tijelima povećat će se za o,03\%, a broj zaposlenih kod korisnika za o,o6\% broja stanovnika. Taj izborni manevar "platit" će rashodi za zaposlene kod korisnika koji će se, u prosjeku, smanjiti za o,6\% ukupnih prihoda.

Binarna varijabla kriza jednoznačno upućuje da se u razdoblju 2009.-II. pogoršava proračunski saldo i to, u prosjeku, za $8,54 \%$ ukupnih prihoda uslijed povećanja rashodne strane proračuna. Ukupni rashodi u promatranom razdoblju porasli su, u prosjeku, za Io,o4\% ukupnih prihoda kao posljedica porasta rashoda poslovanja, u prosjeku, za 8,46\% ukupnih prihoda. Franić (20I2.) analizira zapošljavanje na lokalnoj razini u Hrvatskoj u razdoblju 2008.-II. i pronalazi da je u promatranom razdoblju ukupan broj zaposlenih na teret proračuna jedinica lokalne, područne (regionalne) samouprave porastao za $15 \%$, te $u$ apsolutnom i $\mathrm{u}$ relativnom udjelu porastao $\mathrm{u}$ ukupnim rashodima. Obzirom da $\mathrm{u}$ promatranom razdoblju nije osnovana niti jedna nova jedinica, niti je bilo značajnijih pomaka u decentralizaciji koji bi zahtijevali nova radna mjesta očigledno je riječ polit-ekonomskim motivima zbrinjavanja nezaposlenih. Jednak trend pronalazimo i u promatranom uzorku gradova. Pronalazimo, u prosjeku, povećanje broja zaposlenih u tijelima za o,I7\% i kod korisnika za 0,39\% broja stanovnika, te povećanje rashoda za zaposlene u tijelima, u prosjeku, za I,I7\% ukupnih prihoda i za zaposlene kod korisnika, u prosjeku, za I,9\% ukupnih prihoda. 


\section{TABLIGA 4.}

Rezultati dinamičke panel analize: lokalni izbori

\begin{tabular}{|c|c|c|c|c|c|c|c|c|c|}
\hline & $\begin{array}{l}\text { Saldo } \\
\text { (SAL) }\end{array}$ & $\begin{array}{l}\text { Ukupni } \\
\text { rashodi } \\
\quad(\mathrm{UR})\end{array}$ & $\begin{array}{l}\text { Rashodi } \\
\text { poslovanja } \\
\text { (TC) }\end{array}$ & $\begin{array}{c}\text { Ostali } \\
\text { rashodi } \\
\text { (TC_OST) }\end{array}$ & $\begin{array}{c}\text { Rashodi za } \\
\text { nabavu } \\
\text { nefinancijske } \\
\text { imovine (RNFI) }\end{array}$ & $\begin{array}{l}\text { Zaposleni u } \\
\text { tijelima } \\
\text { (ZPT) }\end{array}$ & $\begin{array}{l}\text { Zaposleni } \\
\text { kod } \\
\text { korisnika } \\
(\mathrm{ZPK})\end{array}$ & $\begin{array}{c}\text { Rashodi za } \\
\text { zaposlene u } \\
\text { tijelima }(\mathbf{R Z T})\end{array}$ & $\begin{array}{c}\text { Rashodi za } \\
\text { zaposlene kod } \\
\text { korisnika (RZK) }\end{array}$ \\
\hline Zavisna varijabla & $\begin{array}{l}-, 1734933^{* *} \\
(, 0866908)\end{array}$ & $\begin{array}{l}-, 03188 \mathrm{I} 4 \\
(, 0995042)\end{array}$ & $\begin{array}{l}-, 40845 I^{*} \\
(, 1519903)\end{array}$ & $\begin{array}{l}\text {,I589668** } \\
\text { (,o759598) }\end{array}$ & $\begin{array}{c}, 2882844^{* *} \\
(, 1347161)\end{array}$ & $\begin{array}{l}\text {,I326647* } \\
\text { (,o503974) }\end{array}$ & $\begin{array}{l}-, \mathrm{I} 2 \mathrm{I} 2 \mathrm{O} 22 \\
(, \mathrm{I} 336 \mathrm{I} 6)\end{array}$ & $\begin{array}{l}, \mathrm{I608494*} \\
(, \mathrm{o} 230038)\end{array}$ & $\begin{array}{l}\text {,I4I4747 } \\
\text { (,o559279) }\end{array}$ \\
\hline BDP jaz & $\begin{array}{l}\mathrm{I}, 44 \mathrm{e}-09^{*} \\
(4,44 \mathrm{e}-\mathrm{IO})\end{array}$ & $\begin{array}{c}-2,07 \mathrm{e}-09^{*} \\
(6,33 \mathrm{e}-\mathrm{IO})\end{array}$ & $\begin{array}{l}\text { I,22e-O9* } \\
(4,43 \mathrm{e}-\mathrm{IO})\end{array}$ & $\begin{array}{l}-7,42 \mathrm{e}-\mathrm{IO}{ }^{*} \\
(2,56 \mathrm{e}-\mathrm{IO})\end{array}$ & $\begin{array}{c}-2,36 \mathrm{e}-09^{*} \\
(4,79 \mathrm{e}-\mathrm{IO})\end{array}$ & $\begin{array}{l}-5,92 \mathrm{e}-\mathrm{II}{ }^{*} \\
(2,5 \mathrm{I} \mathrm{e}-\mathrm{I} 2)\end{array}$ & $\begin{array}{c}-\mathrm{I}, 52 \mathrm{e}-\mathrm{IO}{ }^{*} \\
(8,48 \mathrm{e}-\mathrm{I} 2)\end{array}$ & $\begin{array}{c}-\mathrm{I}, 56 \mathrm{e}-\mathrm{II} \\
(\mathrm{I}, \mathrm{O} 2 \mathrm{e}-\mathrm{IO})\end{array}$ & $\begin{array}{c}3,87 \mathrm{e}-\mathrm{IO}{ }^{* *} \\
(\mathrm{I}, 56 \mathrm{e}-\mathrm{IO})\end{array}$ \\
\hline$B D P p c$ & $\begin{array}{l}4,49 \mathrm{e}-06 * \\
(\mathrm{I}, \mathrm{oIe}-06)\end{array}$ & $\begin{array}{c}-5,62 \mathrm{e}-06 * \\
(1,43 \mathrm{e}-06)\end{array}$ & $\begin{array}{c}-1,35 \mathrm{e}-06 * * \\
(5,37 \mathrm{e}-07)\end{array}$ & $\begin{array}{l}-1,62 \mathrm{e}-07 \\
(6,37 \mathrm{e}-07)\end{array}$ & $\begin{array}{c}-4,72 \mathrm{e}-06^{*} \\
(9,39 \mathrm{e}-07)\end{array}$ & $\begin{array}{c}-8, \mathrm{I} 2 \mathrm{e}-08^{*} \\
(4,35 \mathrm{e}-09)\end{array}$ & $\begin{array}{l}-2,08 \mathrm{e}-07^{*} \\
(2,04 \mathrm{e}-08)\end{array}$ & $\begin{array}{l}-4,04 \mathrm{e}-07 \\
(2,8 \mathrm{Ie}-07)\end{array}$ & $\begin{array}{l}-9,91 \mathrm{I}-08 \\
(3,32 \mathrm{e}-07)\end{array}$ \\
\hline Broj stanovnika & $\begin{array}{c}\text { 6,28e-o6 } \\
(3,94 \mathrm{e}-06)\end{array}$ & $\begin{array}{c}-8,17 \mathrm{e}-06^{* *} \\
(3,88 \mathrm{e}-06)\end{array}$ & $\begin{array}{c}5,15 \mathrm{e}-07 \\
(2,65 \mathrm{e}-06)\end{array}$ & $\begin{array}{l}\text { I,33e-06 } \\
(2,31 \mathrm{I}-06)\end{array}$ & $\begin{array}{l}-8,93 \mathrm{e}-06^{*} \\
(3,04 \mathrm{e}-06)\end{array}$ & $\begin{array}{l}7,32 \mathrm{e}-08^{* *} \\
(4,19 \mathrm{e}-08)\end{array}$ & $\begin{array}{c}3,34 \mathrm{e}-\mathrm{O} 7^{* * *} \\
(\mathrm{I}, 84 \mathrm{e}-\mathrm{O} 7)\end{array}$ & $\begin{array}{c}3,8 \mathrm{Ie}-07 \\
(6,64 \mathrm{e}-07)\end{array}$ & $\begin{array}{l}5,92 \mathrm{e}-07 \\
(\mathrm{I}, 42 \mathrm{e}-06)\end{array}$ \\
\hline IDEO & $\begin{array}{c}\text {,oII6954 } \\
\text { (,oo97328) }\end{array}$ & $\begin{array}{c}-, 0213806^{* *} \\
(, 0099305)\end{array}$ & $\begin{array}{c}\text {,oIII766 } \\
\text { (,oog4053) }\end{array}$ & $\begin{array}{l}\text {,OIIO828** } \\
\text { (,oO55944) }\end{array}$ & $\begin{array}{c}-, \mathrm{O} 258052^{* *} \\
(, \mathrm{O} 20865)\end{array}$ & $\begin{array}{l}-, \text { oooog } 87^{*} \\
(, 0000482)\end{array}$ & $\begin{array}{l}-, \text { OOO298I* } \\
\text { (,oOOII34) }\end{array}$ & $\begin{array}{l}\text {,ooo6I23 } \\
\text { (,oo6o345) }\end{array}$ & $\begin{array}{l}-, 008577 \\
(, 007873)\end{array}$ \\
\hline Izborna godina & $\begin{array}{l}-, 0445553^{*} \\
\text { (,oI24494) }\end{array}$ & $\begin{array}{l}\text {,O2I568 } \\
\text { (,OI48752) }\end{array}$ & $\begin{array}{l}\text {,oo7580I } \\
(, 0059256)\end{array}$ & $\begin{array}{c}, 0028 \mathrm{I} 2 \\
(, 002773 \mathrm{I})\end{array}$ & $\begin{array}{l}-, \text { OOI269I } \\
\text { (,oI52777) }\end{array}$ & $\begin{array}{l}\text {,ooo5471* } \\
\text { (,ooo046I) }\end{array}$ & $\begin{array}{l}\text {,ooI566I* } \\
\text { (,oooI054) }\end{array}$ & $\begin{array}{l}-, \text { Oo654I8* } \\
\text { (,ooli563) }\end{array}$ & $\begin{array}{l}\text {,ool9676 } \\
\text { (,oo29124) }\end{array}$ \\
\hline Izborna godina (-I) & $\begin{array}{l}-,, 0481236 * \\
\text { (,oo98106) }\end{array}$ & $\begin{array}{l}\text {,O341971* } \\
\text { (,oII7483) }\end{array}$ & $\begin{array}{l}, 0052825 \\
\text { (,olO253I) }\end{array}$ & $\begin{array}{l}-, 016565^{*} \\
(, 0053745)\end{array}$ & $\begin{array}{l}\text {,OI25I6 } \\
\text { (,OI2II39) }\end{array}$ & $\begin{array}{l}\text {,ooo4098* } \\
\text { (,ooo0563) }\end{array}$ & $\begin{array}{l}\text {,ooo839I* } \\
\text { (,oooi68) }\end{array}$ & $\begin{array}{c}-, 0040639^{* *} \\
(, 001831)\end{array}$ & $\begin{array}{l}\text {,OIO7797* } \\
\text { (,oO28454) }\end{array}$ \\
\hline Izborna godina $(+\mathrm{I})$ & $\begin{array}{c}-, \mathrm{O} 236024^{* *} \\
(, \mathrm{OIIOI} 45)\end{array}$ & $\begin{array}{l}\text {,o206571** } \\
(, 0089672)\end{array}$ & $\begin{array}{l}\text {,oI5065I } \\
(, 0084286)\end{array}$ & $\begin{array}{l}-, 0032058 \\
(, 0044925)\end{array}$ & $\begin{array}{l}\text {,oo80385 } \\
\text { (,oI3395) }\end{array}$ & $\begin{array}{l}\text {,oolo559* } \\
\text { (,ooo0577) }\end{array}$ & $\begin{array}{l}\text {,oo29689* } \\
\text { (,oool996) }\end{array}$ & $\begin{array}{c}-, 0066008^{*} \\
(, 0008626)\end{array}$ & $\begin{array}{l}, 000708 \mathrm{I} \\
(, 0023724)\end{array}$ \\
\hline Kriza & $\begin{array}{l}\text {-,O547207* } \\
(, 0140535)\end{array}$ & $\begin{array}{l}\text {,O750296* } \\
\text { (,oI70365) }\end{array}$ & $\begin{array}{l}\text {,0667683* } \\
\text { (,o139985) }\end{array}$ & $\begin{array}{l}, 0050259 \\
\text { (,oo8I244) }\end{array}$ & $\begin{array}{l}\text {,OO75472 } \\
\text { (,oI86699) }\end{array}$ & $\begin{array}{l}\text {,ooII67* } \\
\text { (,oooo8I9) }\end{array}$ & $\begin{array}{l}, 0025568^{*} \\
(, 000258 \mathrm{I})\end{array}$ & $\begin{array}{l}\text {,oI62795* } \\
\text { (,oo35466) }\end{array}$ & $\begin{array}{c}\text {,OI8282* } \\
(, 0062298)\end{array}$ \\
\hline Margina & $\begin{array}{l}\text {,005664 } \\
\text { (,oI34177) }\end{array}$ & $\begin{array}{l}-, \text { OII6937 } \\
\text { (,oI39365) }\end{array}$ & $\begin{array}{l}-, 0128702 \\
\text { (,OII3O66) }\end{array}$ & $\begin{array}{l}-, 0039785 \\
(, 0051802)\end{array}$ & $\begin{array}{l}\text {,025805 } \\
\text { (,o183804) }\end{array}$ & $\begin{array}{l}\text {,ooo3477* } \\
\text { (,o000705) }\end{array}$ & $\begin{array}{c}, 0005276^{* * *} \\
(, 000294)\end{array}$ & $\begin{array}{c}-, 0049563^{* *} \\
\text { (,o023088) }\end{array}$ & $\begin{array}{l}-, \text { OII5283** } \\
\text { (,oo45706) }\end{array}$ \\
\hline _cons & $\begin{array}{c}-, 963466^{*} \\
(, 3004852)\end{array}$ & $\begin{array}{l}2,284333^{*} \\
(, 305952)\end{array}$ & $\begin{array}{l}\mathrm{I}, 0985 \mathrm{I} 6^{*} \\
(, 2950632)\end{array}$ & $\begin{array}{c}, \text { OO27445 } \\
(, 224 I I I)\end{array}$ & $\begin{array}{l}\text { I,599955* } \\
(, 3069513)\end{array}$ & $\begin{array}{l}-, \text { ooliI36 } \\
\text { (,oo365I) }\end{array}$ & $\begin{array}{l}-, \text {,olo6099 } \\
(, 027345 \mathrm{I})\end{array}$ & $\begin{array}{c}, 04637 \\
(, 0753964)\end{array}$ & $\begin{array}{c}\text {,O522293 } \\
(, \mathrm{I} 3734)\end{array}$ \\
\hline $\mathrm{N}$ & I68 & I68 & I68 & I68 & $\mathrm{I} 68$ & I68 & I68 & 168 & 168 \\
\hline $\begin{array}{l}\text { Sargan test } \\
\text { (p-vrijednost) }\end{array}$ & O,9999 & I,OOOO & I,OOOO & I,OOOO & o,9994 & 0,9883 & o,9933 & O,9995 & I,OOOO \\
\hline $\mathrm{AR}(\mathrm{I})$ test & 0,0I39 & 0,0140 & 0,3844 & 0,0280 & O,OII3 & 0,0003 & 0,0026 & 0,0363 & 0,0475 \\
\hline $\mathrm{AR}(2)$ test & 0,6785 & 0,9105 & $0,086 \mathrm{I}$ & 0,0609 & 0,4385 & 0,6835 & 0,1300 & 0,5006 & 0,7927 \\
\hline
\end{tabular}

Napomena: * **, *** označava statističku značajnost na razini od I\%, 5\% i 1o\%. Standardne pogreške su u zagradama.

Izvor: izračun autora. 
Kada se posebno analiziraju lokalni izbori na odabranom uzorku gradova dolazimo do potvrde hipoteze o postojanju PBC-a. Sukladno nalazima Naruhiko Sakurai i Menezes-Filho (20II.) pronalazimo porast proračunskog deficita u izbornoj godini, u prosjeku, za 4,45\% ukupnih prihoda. Budući da smo u analizi lokalnih izbora dodali i binarne varijable za predizbornu i postizbornu godinu vidimo da je proračunski saldo i u njima statistički značajan. U predizbornoj godini deficit, u prosjeku, poraste za 4,8I\% ukupnih prihoda, dok u postizbornoj godini, u prosjeku, poraste za 2,36\% ukupnih prihoda. Rašić Bakarić i dr. (2013.) na uzorku od I27 gradova i Bratić (2008.) u analizi procesa odlučivanja o lokalnim proračunima u Hrvatskoj zaključuju da politička opredijeljenost ne utječe na kretanje proračunskih varijabli. Drugim riječima, svi političari pokušavaju oportunistički manipulirati proračunskim stavkama kako bi osigurali reizbor.

U modelu s ukupnim rashodima, statistički značajan porast postoji u predizbornoj (u prosjeku za 3,4I\% ukupnih prihoda) i postizbornoj godini (u prosjeku za 2,06\% ukupnih prihoda). Unutar stavke ukupni rashodi u sva tri promatrana perioda, statistički značajni su još samo ostali rashodi koji se, u prosjeku, smanjuju za 1,65\% ukupnih prihoda u predizbornoj godini.

U sva tri promatrana razdoblja, bilježimo i statistički značajan porast varijabli koje mjere prosječnu zaposlenost u tijelima i kod korisnika, s najizraženijim koeficijentima u postizbornoj godini (o,IO5\% i o,296\% ukupne populacija). U situaciji kad je ishod izbora neizvjestan, binarna varijabla margina u izbornoj godini također potvrđuje statističku značajnost i pozitivni koeficijent navedenih varijabli (o,034\% i o,052\% ukupnih prihoda). Navedena pojava upućuje na motiviranost političara na vlasti da osiguravanjem radnih mjesta osiguraju političku podršku na lokalnim izborima. Budući da je odaziv na lokalne izbore puno manji od odaziva na parlamentarne izbore (DIP, 2OI3.) i granične koristi takvog poteza su puno veće.

Binarna varijabla margina upućuje na smanjenje rashoda za plaće u tijelima (o,49\% ukupnih prihoda) i kod korisnika (I,I5\% ukupnih prihoda). Istodobno rashodi za zaposlene u tijelima, u prosjeku, smanjuju se u sva tri promatrana perioda, s najizraženijim koeficijentom u postizbornoj godini (o,66\% ukupnih prihoda). S druge strane, rashodi za zaposlene kod korisnika, u predizbornoj godini, bilježe statistički značajan rast (I,O7\% ukupnih prihoda). Možemo zaključiti da i u slučaju lokalnih izbora dolazi do određenog restrukturiranja na rashodnoj strani proračuna kako bi se povećani broj zaposlenih mogao financirati. Porast "vidljivih" izdataka (broja zaposlenih i rashoda za plaće) u kombinaciji s porastom proračunskog deficita upućuje na teorijske pretpostavke Rogoffovog modela PBC-a. Obzirom na proračunska ograničenja koja vrijede za gradove, političari na vlasti svjesni su da stvaranje proračunskog deficita može biti minimalno što je potvrđeno i stavkama koje se mijenjaju u izbornim godinama (prosječan broj zaposlenih i rashodi za zaposlene u tijelima). Zakonodavac je time političarima na lokalnoj razini oduzeo "oružje", ali im nije umanjio motiv i sklonost oportunističkom ponašanju. Nadalje, postojanje proračunskog ograničenja za zaduženje de facto dokida razlikovanje kompetentnog i nekompetentnog političara na vlasti. U promatranom periodu srednja vrijednost proračunskog salda (ispis AI) upućuje na deficit, odnosno svi političari na vlasti kreiraju deficit u promatranom razdoblju. Pitanje je samo na koji način restrukturiraju stavke na rashodovnoj strani i pogađaju preferencije biračkog tijela.

Identične varijable statistički su značajne za binarnu varijablu kriza (SAl, UR, TC, ZPT, ZPK, RZT i RZK) kao i kad se promatraju svi izbori zajedno. Svi procijenjeni koeficijenti su pozitivni i niži od koeficijenata procijenjenih za lokalne i prlamentarne izbore zajedno, osim koeficijenta za rashode za zaposlene u tijelima koji bilježi porast, u prosjeku, za I,62\% ukupnih prihoda. Dodatno, procijenjeni koeficijenti imaju potpuno isti predznak i veličinu i kod lokalnih i kod parlamentarnih izbora. 


\section{Tablica 5.}

Rezultati dinamičke panel analize: parlamentarni izbori

\begin{tabular}{|c|c|c|c|c|c|c|c|c|c|}
\hline & $\begin{array}{l}\text { Saldo } \\
\text { (SAL) }\end{array}$ & $\begin{array}{l}\text { Ukupni } \\
\text { rashodi } \\
\quad(\mathrm{UR})\end{array}$ & $\begin{array}{l}\text { Rashodi } \\
\text { poslovanja } \\
\text { (TG) }\end{array}$ & $\begin{array}{c}\text { Ostali } \\
\text { rashodi } \\
\text { (TC_OST) }\end{array}$ & $\begin{array}{c}\text { Rashodi za } \\
\text { nabavu } \\
\text { nefinancijske } \\
\text { imovine }(\text { RNFI) }\end{array}$ & $\begin{array}{c}\text { Zaposleni u } \\
\text { tijelima } \\
(\text { ZPT })\end{array}$ & $\begin{array}{c}\text { Zaposleni kod } \\
\text { korisnika } \\
(\mathrm{ZPK})\end{array}$ & $\begin{array}{c}\text { Rashodi za } \\
\text { zaposlene u } \\
\text { tijelima (RZT) }\end{array}$ & $\begin{array}{c}\text { Rashodi za } \\
\text { zaposlene kod } \\
\text { korisnika (RZK) }\end{array}$ \\
\hline Zavisna varijabla & $\begin{array}{l}-,, 1734933^{* *} \\
(, 0866908)\end{array}$ & $\begin{array}{c}-, 03188 I 4 \\
(, 0995042)\end{array}$ & $\begin{array}{l}-, 40845 I^{*} \\
(, 1519903)\end{array}$ & $\begin{array}{l}\text {,I589668** } \\
\text { (,o759598) }\end{array}$ & $\begin{array}{l}, 2882844^{* *} \\
(, 134716 \mathrm{I})\end{array}$ & $\begin{array}{l}\text {,I326647* } \\
(, 0503974)\end{array}$ & $\begin{array}{l}-, \mathrm{I} 2 \mathrm{I} 2 \mathrm{O} 22 \\
(, \mathrm{I} 336 \mathrm{I} 6)\end{array}$ & $\begin{array}{l}\text {,I608494* } \\
(, 0230038)\end{array}$ & $\begin{array}{l}\text {,I4I4747** } \\
\text { (,O559279) }\end{array}$ \\
\hline BDP jaz & $\begin{array}{l}\mathrm{I}, 44 \mathrm{e}-0{ }^{*} \\
(4,44 \mathrm{e}-\mathrm{IO})\end{array}$ & $\begin{array}{c}-2,07 e-09 \\
(6,33 \mathrm{e}-10)\end{array}$ & $\begin{array}{l}\mathrm{I}, 22 \mathrm{e}-09^{*} \\
(4,43 \mathrm{e}-\mathrm{IO})\end{array}$ & $\begin{array}{c}-7,42 \mathrm{e}-\mathrm{IO} \mathrm{O}^{*} \\
(2,56 \mathrm{e}-\mathrm{IO})\end{array}$ & $\begin{array}{c}-2,36 \mathrm{e}-09^{*} \\
(4,79 \mathrm{e}-\mathrm{IO})\end{array}$ & $\begin{array}{l}-5,92 \mathrm{e}-\mathrm{II} \\
(2,5 \mathrm{I} \mathrm{e}-\mathrm{I} 2)\end{array}$ & $\begin{array}{c}-\mathrm{I}, 52 \mathrm{e}-\mathrm{IO} * \\
(8,48 \mathrm{e}-\mathrm{I} 2)\end{array}$ & $\begin{array}{l}-\mathrm{I}, 56 \mathrm{e}-\mathrm{II} \\
(\mathrm{I}, \mathrm{O} 2 \mathrm{e}-\mathrm{IO})\end{array}$ & $\begin{array}{c}3,87 \mathrm{e}-10^{* *} \\
(\mathrm{I}, 56 \mathrm{e}-\mathrm{IO})\end{array}$ \\
\hline BDP pc & $\begin{array}{l}4,49 \mathrm{e}-06 * \\
(\mathrm{I}, \mathrm{OIe}-\mathrm{o6})\end{array}$ & $\begin{array}{c}-5,62 \mathrm{e}-06 * \\
(1,43 \mathrm{e}-06)\end{array}$ & $\begin{array}{c}-1,35 \mathrm{e}-06^{* *} \\
(5,37 \mathrm{e}-07)\end{array}$ & $\begin{array}{l}-1,62 \mathrm{e}-07 \\
(6,37 \mathrm{e}-07)\end{array}$ & $\begin{array}{c}-4,72 \mathrm{e}-06^{*} \\
(9,39 \mathrm{e}-07)\end{array}$ & $\begin{array}{l}-8, \mathrm{I2e}-08^{*} \\
(4,35 \mathrm{e}-09)\end{array}$ & $\begin{array}{l}-2,08 \mathrm{e}-07^{*} \\
(2,04 \mathrm{e}-08)\end{array}$ & $\begin{array}{l}-4,04 \mathrm{e}-07 \\
(2,8 \mathrm{Ie}-07)\end{array}$ & $\begin{array}{l}-9,91 \mathrm{Ie}-08 \\
(3,32 \mathrm{e}-07)\end{array}$ \\
\hline Broj stanovnika & $\begin{array}{c}6,28 \mathrm{e}-06 \\
(3,94 \mathrm{e}-06)\end{array}$ & $\begin{array}{c}-8,17 \mathrm{e}-06^{* *} \\
(3,88 \mathrm{e}-06)\end{array}$ & $\begin{array}{c}5,15 \mathrm{e}-07 \\
(2,65 \mathrm{e}-06)\end{array}$ & $\begin{array}{c}\text { I,33e-06 } \\
(2,31 \mathrm{I}-06)\end{array}$ & $\begin{array}{l}-8,93 \mathrm{e}-06^{*} \\
(3,04 \mathrm{e}-06)\end{array}$ & $\begin{array}{c}7,32 \mathrm{e}-08^{* * *} \\
(4,19 \mathrm{e}-08)\end{array}$ & $\begin{array}{c}3,34 \mathrm{e}-\mathrm{O} 7^{* * *} \\
(\mathrm{I}, 84 \mathrm{e}-\mathrm{O} 7)\end{array}$ & $\begin{array}{c}3,81 \mathrm{Ie}-07 \\
(6,64 \mathrm{e}-07)\end{array}$ & $\begin{array}{l}5,92 \mathrm{e}-07 \\
(\mathrm{I}, 42 \mathrm{e}-06)\end{array}$ \\
\hline IDEO & $\begin{array}{l}\text {,oII6954 } \\
\text { (,oo97328) }\end{array}$ & $\begin{array}{l}-, 0213806^{* *} \\
(, 0099305)\end{array}$ & $\begin{array}{c}\text {,oIII766 } \\
(, 0094053)\end{array}$ & $\begin{array}{l}\text {,OIIO828** } \\
\text { (,oO55944) }\end{array}$ & $\begin{array}{c}-, 0258052^{* *} \\
(, 0120865)\end{array}$ & $\begin{array}{c}-, 0000987^{* *} \\
(, 0000482)\end{array}$ & $\begin{array}{l}\text {-,ooo2981* } \\
\text { (,oooII34) }\end{array}$ & $\begin{array}{l}\text {,ooo6123 } \\
\text { (,oo60345) }\end{array}$ & $\begin{array}{l}-, 008577 \\
(, 007873)\end{array}$ \\
\hline Izborna godina & $\begin{array}{l}\text {,O445553* } \\
\text { (,o124494) }\end{array}$ & $\begin{array}{c}-, 021568 \\
(, 0148752)\end{array}$ & $\begin{array}{l}-, 0075801 \\
(, 0059256)\end{array}$ & $\begin{array}{l}-, 0028 \mathrm{I} 2 \\
(, \mathrm{OO} 2773 \mathrm{I})\end{array}$ & $\begin{array}{l}\text {,OOI2691 } \\
\text { (,oI52777) }\end{array}$ & $\begin{array}{l}-, 000547 I^{*} \\
(, 000046 \mathrm{I})\end{array}$ & $\begin{array}{l}-, \text {,ooI566I* } \\
\text { (,oooI054) }\end{array}$ & $\begin{array}{l}\text {,Oo65418* } \\
\text { (,ooli563) }\end{array}$ & $\begin{array}{l}-, 0019676 \\
(, 0029124)\end{array}$ \\
\hline Izborna godina (-I) & $\begin{array}{l}\text {,0209529** } \\
(, 0099074)\end{array}$ & $\begin{array}{c}-, 0009108 \\
(, 012 \mathrm{IIO} 3)\end{array}$ & $\begin{array}{l}\text {,oo7485 } \\
\text { (,oo9289) }\end{array}$ & $\begin{array}{l}-, 0060179 \\
(, 004574 I)\end{array}$ & $\begin{array}{l}\text {,oo93077 } \\
\text { (,olo3009) }\end{array}$ & $\begin{array}{l}, 0005088^{*} \\
(, 0000262)\end{array}$ & $\begin{array}{l}\text {,OOI4O28* } \\
\text { (,oooI245) }\end{array}$ & $\begin{array}{l}-, 0000589 \\
(, 0010896)\end{array}$ & $\begin{array}{l}-, \text { OOI2595 } \\
(, 0018583)\end{array}$ \\
\hline Izborna godina $(+\mathrm{I})$ & $\begin{array}{l}-, 0035683 \\
(, 0126467)\end{array}$ & $\begin{array}{l}\text {,OI26291 } \\
\text { (oI43909) }\end{array}$ & $\begin{array}{l}-, 0022976 \\
(, 0099355)\end{array}$ & $\begin{array}{l}-, 019377^{*} \\
(, 0047772)\end{array}$ & $\begin{array}{l}\text {,OI3785I } \\
(, \mathrm{OI} 2 \mathrm{I} 386)\end{array}$ & $\begin{array}{l}-, \text {,oooI373* } \\
\text { (,oooo355) }\end{array}$ & $\begin{array}{l}-,, 0007269^{*} \\
\text { (,oooli82) }\end{array}$ & $\begin{array}{l}, 0024779 \\
(, 0016217)\end{array}$ & $\begin{array}{l}\text {,oo88I2I* } \\
(, 0032807)\end{array}$ \\
\hline Kriza & $\begin{array}{l}-, 0547207^{*} \\
\text { (,o140535) }\end{array}$ & $\begin{array}{l}\text {,0750296* } \\
\text { (,o170365) }\end{array}$ & $\begin{array}{l}\text {,o667683* } \\
\text { (,o139985) }\end{array}$ & $\begin{array}{l}\text {,0050259 } \\
\text { (,o08I244) }\end{array}$ & $\begin{array}{l}\text {,oO75472 } \\
\text { (,ol86699) }\end{array}$ & $\begin{array}{l}\text {,oOII67* } \\
\text { (,oooo8I9) }\end{array}$ & $\begin{array}{l}\text {,OO25568* } \\
\text { (,oOO258I) }\end{array}$ & $\begin{array}{l}\text {,OI62795* } \\
\text { (,oo35466) }\end{array}$ & $\begin{array}{l}\text {,o18282* } \\
\text { (,o062298) }\end{array}$ \\
\hline Margina & $\begin{array}{l}\text {,o05664 } \\
\text { (,o134177) }\end{array}$ & $\begin{array}{l}-, \text { OII6937 } \\
\text { (,oI39365) }\end{array}$ & $\begin{array}{l}-, 0128702 \\
\text { (,oII3066) }\end{array}$ & $\begin{array}{l}-, 0039785 \\
(, 0051802)\end{array}$ & $\begin{array}{l}\text {,025805 } \\
\text { (,0183804) }\end{array}$ & $\begin{array}{l}\text {,0003477* } \\
\text { (,0000705) }\end{array}$ & $\begin{array}{c}, 0005276^{* * *} \\
(, 000294)\end{array}$ & $\begin{array}{c}-, 0049563^{* *} \\
\text { (,o023088) }\end{array}$ & $\begin{array}{c}-, \text { OII5283*** } \\
\text { (,oo45706) }\end{array}$ \\
\hline _cons & $\begin{array}{c}-\mathrm{I}, 008 \mathrm{O} 2 \mathrm{I}^{*} \\
(, 3 \mathrm{OI} 3278)\end{array}$ & $\begin{array}{l}2,30590 I^{*} \\
(, 3056829)\end{array}$ & $\begin{array}{l}\text { I,I06096* } \\
(, 2946027)\end{array}$ & $\begin{array}{l}, 0055566 \\
(, 2248378)\end{array}$ & $\begin{array}{l}\text { I,598686* } \\
(, 306079 \mathrm{I})\end{array}$ & $\begin{array}{l}-, 0005666 \\
(, 0036633)\end{array}$ & $\begin{array}{l}-, 0090438 \\
(, 02738 \mathrm{II})\end{array}$ & $\begin{array}{l}\text {,0398282 } \\
(, 0754164)\end{array}$ & $\begin{array}{l}\text {,O54I969 } \\
(, I 39 I I 3 I)\end{array}$ \\
\hline $\mathrm{N}$ & 168 & I68 & $\mathrm{I} 68$ & I68 & 168 & I68 & $\mathrm{I} 68$ & 168 & I68 \\
\hline $\begin{array}{l}\text { Sargan test } \\
\text { (p-vrijednost) }\end{array}$ & O,9999 & I,OOOO & I,OOOO & I,OOOO & o,9994 & 0,9883 & o,9933 & o,9995 & I,OOOO \\
\hline $\mathrm{AR}(\mathrm{I})$ test & o,0139 & O,OI40 & 0,3844 & 0,0280 & O,OII3 & 0,0003 & 0,0026 & 0,0363 & 0,0475 \\
\hline $\mathrm{AR}(2)$ test & 0,6785 & 0,9105 & $0,086 \mathrm{I}$ & 0,0609 & 0,4385 & 0,6835 & 0,1300 & 0,5006 & 0,7927 \\
\hline
\end{tabular}

Napomena: * **, *** označava statističku značajnost na razini od ı\%, 5\% i 10\%. Standardne pogreške su u zagradama.

Izvor: izračun autora. 
Analiza parlamentarnih izbora u izbornoj godini rezultira statistički značajnim varijablama (SAL, ZPT, ZPK, RZT) koje imaju suprotan predznak procijenjenih koeficijenata u odnosu na analizu lokalnih izbora. Odnosno, bilježimo smanjenje proračunskog deficita (4,45\% ukupnih prihoda) i pad prosječnog broja zaposlenih u tijelima (o,05\% broja stanovnika) i kod korisnika (o,I5\% broja stanovnika). Rezultat je sukladan dobivenim rezultatima na zajedničkom uzorku analize svih izbora, dok rashodi za zaposlene u tijelima u izbornoj godini, u prosjeku, rastu za o,65\% ukupnih prihoda. U predizbornoj godini prosječan broj zaposlenih u tijelima i kod korisnika raste, dok se proračunski deficit smanjuje. Postizborna godina bilježi statistički značajno smanjenje ostalih rashoda i prosječnog broja zaposlenih u tijelima i kod korisnika, uz povećanje rashoda za zaposlene kod korisnika. Predznaci i procijenjeni koeficijenti uz binarne varijable margina i kriza imaju potpuno isti predznak i veličinu i kod lokalnih i kod parlamentarnih izbora.

\section{ZAKLJUǦAK}

Polit-ekonomska analiza informacijskih, tehničkih i političkih ograničenja s kojima se suočavaju političari na vlasti, ali i ostali sudionici unutar teorije javnog izbora, postaje sve relevantnija $u$ okruženju koji obilježava fiskalna konsolidacija. Sukladno Aristotelovom poimanju po kojem je čovjek politička "životinja” proizlazi da pojedinac, izravno i neizravno, kreira okruženje u kojem se odvija tržišno i netržišno djelovanje. Stoga svaka analiza netržišnog odlučivanja, kao što su odluke u proračunskom procesu, koja zanemaruje politička ograničenja, je nepotpuna i neadekvatna.

U radu je istražena povezanost teorije PBC-a i njenih empirijskih implikacija na uzorku hrvatskih gradova. Također, analizirane su fiskalne strategije političara na vlasti koji teže reizboru unutar institucionalno postavljenih ograničenja na lokalnoj razini. Empirijski je testirana koreliranost proračunskih stavki odabranih hrvatskih gradova (I9 županijskih središta, Grad Zagreb i Pula) s izbornim rezultatima u razdoblju 2003.-II. godine. Korištena je dinamička panel analiza i ArellanoBondov GMM procjenitelj u dva koraka. Uz empirijski dio, u radu su prikazani različiti teorijski modeli političko-proračunskih ciklusa (PBC), te je dan pregled empirijskih istraživanja o postojanju PBC-a u razvijenim i tranzicijskim zemljama, te u zemljama u razvoju.

Procijenjeno je ukupno dvadeset i sedam ekonometrijskih modela na tri različita uzorka. Prvih devet modela odnosi se na zajedničku analizu utjecaja lokalnih i parlamentarnih izbora na proračunske varijable u odabranom uzorku gradova; sljedećih devet na utjecaje lokalnih izbora i posljednjih devet na utjecaje parlamentarnih izbora.

Rezultati dinamičke panel analize na zajedničkom uzorku upućuju na odbacivanje hipoteze o postojanju oportunističkih PBC-a na razini promatranih hrvatskih gradova. U izbornim godinama proračunski deficit i ukupni rashodi se smanjuju što je suprotno teorijskim pretpostavkama modela. Uslijed institucionalnih ograničenja zaduživanja gradova političari na vlasti manipuliraju strukturom rashoda kako bi maksimalizirali reizbor. Povećanje tekućih (rashodi za zaposlene u tijelima i ostali rashodi) i smanjenje kapitalnih izdataka (rashodi za nabavu nefinancijske imovine) za političare na vlasti predstavlja drugu najbolju strategiju. Time se naglašava rentijerska uloga birokracije u izbornom procesu, sukladno Niskanenovim pretpostavkama o maksimalizaciji proračuna. Istodobno, to predstavlja racionalnu odluku političara na vlasti, koji računaju da će birokracija češće glasovati u odnosu na ostatak biračkog tijela. U situaciji kad je ishod izbora neizvjestan rezultati procijenjenih modela upućuju na povećanje prosječnog broja zaposlenih u tijelima i kod korisnika. Dodatno, bilježi se i povećanje rashoda za nabavu nefinancijske imovine uz istodobno smanjenje rashoda poslovanja. 
Na uzorku parlamentarnih izbora rezultati analize ne odstupaju značajno od onih dobivenih na zajedničkom uzorku. Proračunski deficit se smanjuje u izbornim godinama, dok ukupni rashodi nisu statistički značajni pri uobičajenim razinama signifikantnosti. Porast prosječnog broja zaposlenih u tijelima i kod korisnika, uz istodobno smanjenje rashoda za plaće obilježava strategiju političara na vlasti u izbornim godinama.

Potvrda hipoteze o postojanju oportunističkih PBC-a na razini promatranih hrvatskih gradova pronađena je u uzorku koji analizira samo lokalne izbore. Navedena potvrda nalazi uporište u modelu sa saldom, sukladno teorijskim predviđanjima Rogoffova modela asimetričnosti informacija prikazanim u poglavlju 3. Također, u modelima s prosječnim brojem zaposlenih u tijelima i kod korisnika, nalazimo potvrdu istog obrasca ponašanja političara na vlasti. U navedenim modelima, koeficijenti su statistički značajni i njihovi predznaci se poklapaju s teorijskim predviđanjima.

Rezultati dinamičke panel analize, u sva tri uzorka, ne potvrđuju dodatnu hipotezu, po kojoj porast javnih izdataka slijedi kad se nositelji izvršne vlasti podudaraju na središnjoj i lokalnoj razini. Budući da su središnja i lokalna razina povezane kroz financiranje decentraliziranih funkcija i model fiskalnog izravnanja političari na vlasti na središnjoj razini nemaju prostor za diskrecijske odluke u izbornom ciklusu.

Ograničenje ovog rada proizlazi iz relativno kratke vremenske serije podataka. Nadalje, potpunija analiza oportunističkih motiva političara na vlasti u gradovima trebala bi uključivati uz lokalne proračune i komunalna poduzeća u vlasništvu gradova pomoću kojih gradovi izbjegavaju proračunska ograničenja zaduživanja. Potonje ujedno predstavlja i smjer daljnjeg istraživanja. Sukladno postavkama modela asimetričnosti preferencija političara na vlasti i izrazitoj fiskalnoj centraliziranosti Hrvatske, u daljnjim istraživanjima bi bilo zanimljivo analizirati utjecaj ciljane potrošnje iz proračuna središnje države prema pojedinim društvenim skupinama i/ili geografskim jedinicama (gradovima i županijama), te rezultate izbora na lokalnoj i regionalnoj razini. 


\section{Prilog}

\section{ISPIS AI.}

Deskriptivna analiza

- summarize bdp_jaz bdp_pc br_stan rnfi rzk rzt sal tc tc_ost ur zpk zpt

Variable |
Obs

Izvor: izračuna autora.

\section{ISPIS A2.}

Korelacijska matrica (razina značajnosti 5\%)

- pwcorr bdp_jaz bdp_pc br_stan ideo izb_god izb_god_1_izb_god_1_01 kriza margina rnfi rzk rzt sal tc tc_ost ur zpk zpt, star(5)

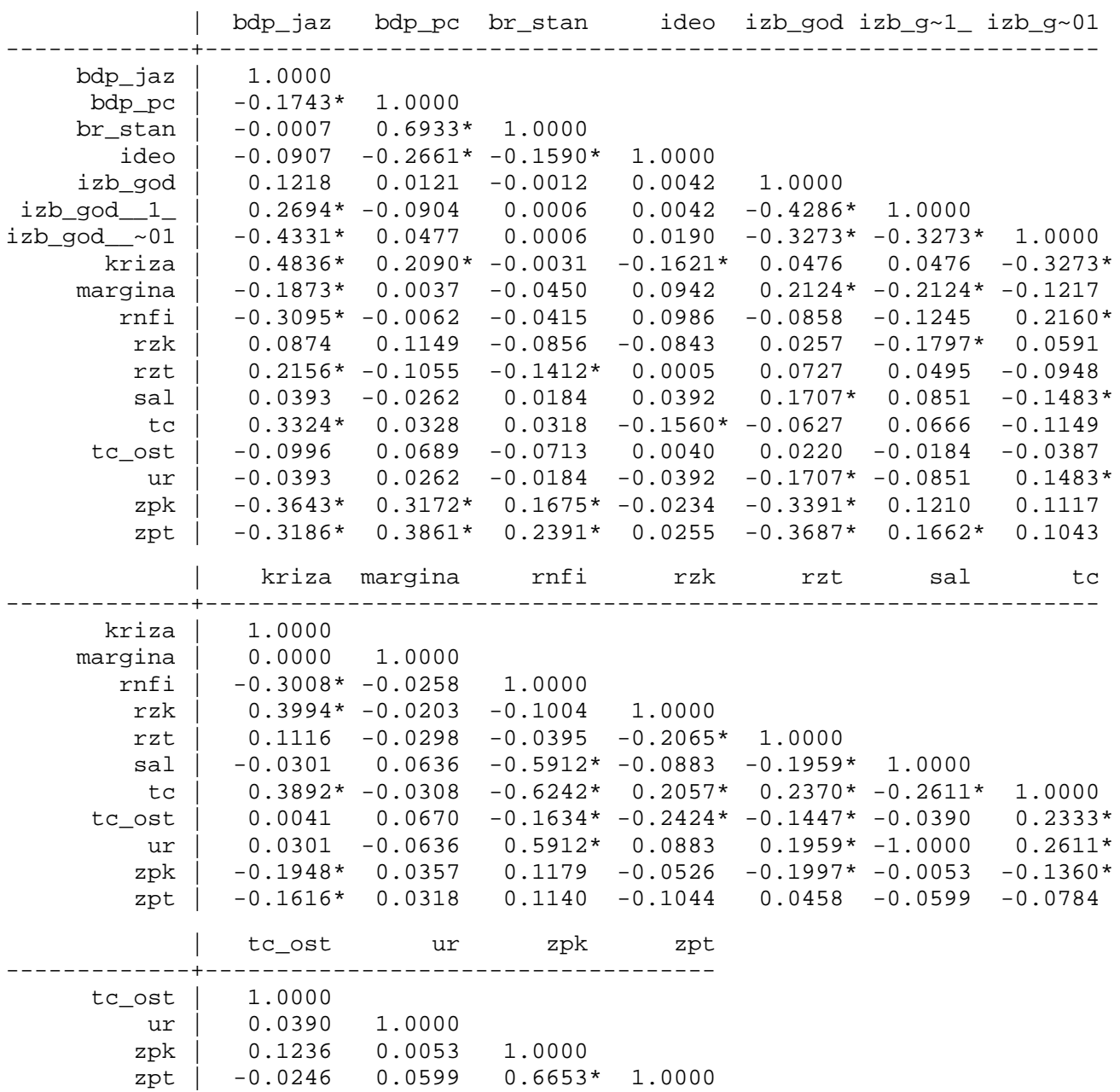




\section{REFERENGE}

I. Akhmedov, A., i Zhuravskaya, E., 2004. Opportunistic Political Cycles: Test in a Young Democracy Setting. Quarterly Journal of Economics, II9(4), str. I3OI-I338. doi: IO.II62/O033553042476206

2. Alesina, A., 1988. Macroeconomics and Politics. NBER Macroeconomics Annual, 3, str. I3-62. doi: IO.2307/3584936

3. Alesina, A. [et al.], 1997. Political Cycles and the Macroeconomy. London: The MIT Press.

4. Alt, J. i Lassen, D., 2006. Transparency, Political Polarization, and Political Budget Cycles in OECD Countries. American Journal of Political Science, 50(3), str. 530-550. doi: IO.IIII/j.I54O5907.2006.00200.x

5. Arellano, M. i Bond, S., I99I. Some test of specification for Panel data, Monte Carlo Evidence and Application to Employment Equations. Review of Economic Studies, 58(2), str. 277-297. doi: 10.2307/2297968

6. Arnsperger, C. i Varoufakis, Y., 2006. What is Neoclassical Economics? [online]. Dostupno na: <http://www.paecon.net/PAEReview/issue38/ArnspergerVaroufakis38.htm〉.

7. Bajo, A. i Bronić, M., 2007. Assessments of the Effectiveness of the Croatian Fiscal Equalisation Model. Financial Theory and Practice, 3I(I), str. I-26.

8. Bajo, A. i Jurlina Alibegović, D., 2008. Javne financije lokalnih jedinica vlasti. Zagreb: Školska knjiga.

9. Baltagi, B. H., 2008. Econometric Analysis of Panel Data. West Sussex: JohnWiley\&Sons.

IO. Bond, S. R., 2002. Dynamic panel data models: a guide to micro data methods and practice. Portuguese Economic Journal, I(2), str. I4I-I62. doi: I0.I007/sio258-002-00o9-9

II. Bratić, V., 2008. Odlučivanje o lokalnim proračunima: između sna i jave. Zagreb: Institut za javne financije.

12. Brender, A. i Drazen, A., 2004. Political Budget Cycles in New versus Established Democracies. NBER Working Paper Series, No. IO539, str. I-28.

I3. Brender, A. i Drazen, A., 2009. How do Budget Deficits and Economic Growth Affect Reelection Prospects? Evidence from a Large Panel of Countries. American Economic Review, 98(5), str. 22O32220. doi: Io.I257/aer.98.5.2203

I4. Bronić, M., 20Io. Evaluating the current equalization grant to counties in Croatia. Financial Theory and Practice, 34(I), str. 25-52.

I5. Buchanan, J. M., 2005. Public Choice Society [online]. Dostupno na: 〈http://www.gmu.edu/centers/publicchoice/pdf\%2olinks/Booklet.pdf>.

I6. Drazen, A., 200o. Political Economy in Macroeconomics. New Jersey: Princeton University Press.

I7. Drazen, A. i Eslava, M., 2005. Electoral Manipulation via Expenditure Composition: Theory and Evidence. NBER Working Paper Series, No. IIO85, str. I-27.

I8. Drazen, A. i Eslava, M., 2006. Pork Barrel Cycles. NBER Working Paper Series, No. 12190, str. I-34.

I9. DZS, 2013. Statistički ljetopis 2012. [online]. Zagreb: Državni zavod za statistiku. Dostupno na: $\langle$ http://www.dzs.hr/>.

20. DIP, 20I3. Arhiva izbora [online]. Zagreb: Državno izborno povjerenstvo. Dostupno na: $\langle$ http://www.izbori.hr/izbori/dip_ws.nsf/public/index?OpenForm〉.

2I. Eslava, M., 20II. The Political Economy of Fiscal Deficits: A Survey. Journal of Economic Survey, 25(4), str. 645-673. doi: IO.IIII/j.I467-64I9.2010.00647.x

22. Franić, J., 2012. Employment at the local government level in the Republic of Croatia during the economic crisis. Newsletter, No. 71. doi: 10.3326/nle.2012.71

23. Galli, E. i Rossi, S. P., 2002. Political budget cycles: The case of the Western German Laender. Public choice, IIO(3-4), str. 283-303. doi: IO.IO23/A:IOI3089504557

24. Gonzales, M., 2002. Do Changes in Democracy affect the Political Budget Cycle? Evidence from Mexico. Review of Development Economics, 6(2), str. 204-224. doi: Io.IIII/I467-9361.00I50

25. Hair, J. F. [et al.], I995. Multivariate Data Analysis. New Jersey: Prentice Hall.

26. Hallerberg, M. i de Souza, L. V., 200o. The Political Business Cycles of EU Accession Countries. European Union Politics, 3(2), str. 23I-25O. doi: 10.II77/I465II6502003002005

27. Jurlina Alibegović, D. [et al.], 20IO. Analitičke podloge za učinkovitu decentralizaciju u Hrvatskoj: projektna studija. Zagreb: Ekonomski institut. 
28. Katsimi, M. i Sarantides, V., 2012. Do Elections Affect the Composition of Fiscal Policy in Developed, Established Democracies?. Public Choice, I5I(I-2), str. 325-362. doi: Io.IOO7/sIII27-OIO9749-8

29. Khemani, S., 2004. Political cycles in a developing economy: effect of elections in Indian states. Journal of Development Economics, 73(I), str. 125-154. doi: I0.IOI6/j.jdeveco.2003.01.002

30. Klašnja, M., 2008. Electoral rules, forms of government and political budget cycles in transition countries. Paneconomicus, 55(2), str. 185-218. doi: 10.2298/PANo802185K

3I. Lemieux, P., 2004. The Public Choice Revolution [online]. Dostupno na: 〈http://www.cato.org/pubs/regulation/regv27n3/v27n3-2.pdf>.

32. Lohmann, S., 2006. The Non-Politics of Monetary Policy u: B. R. Weingast i D. A. Wittman, ur. The Oxford Handbook of Political Economy. New York: Oxford University Press Inc, str. 523-544.

33. Maurel, M., 2006. The Political Business Cycles in the EU enlarged. Slovenian Journal for Money and Banking, 55(II), str. 38-4I.

34. McLean, I., 1997. Uvod u javni izbor. Zagreb: Fakultet političkih znanosti.

35. Ministarstvo financija RH, 20I3. Lokalni proračun arhiva [online]. Dostupno na: 〈http://www.mfin.hr/hr/lokalni-proracun-2002〉.

36. Mueller, D. C., 2003. Javni izbor III. Zagreb: Masmedija.

37. Naruhiko Sakurai, S. i Menezes-Filho, N., 20II. Opportunistic and Partisan Election Cycles in Brazil: New Evidence at the Municipal Level. Public Choice, I48(I), str. 233-247. doi: I0.IO07/sIII27OIO-9654-I

38. Persson, T. i Tabellini, G., 200o. Political Economics. London: The MIT Press.

39. Persson, T., i Tabellini, G., 2002. Do electoral cycles differ across political systems?. Innocenzo Gasparini Institute for Economic Research (IGIER), Università Bocconi, Working Papers, No. 232, str. I23.

4O. Petak, Z., 2008. Javne politike i problemi modernog upravljanja. Hrvatska javna uprava, 8(2), str. 443-462.

4I. Pettersson Lidbom, P., 200o. A test of the rational electoral-cycle hypothesis u: P. Pettersson, ur. Elections, party Politics and Economic Policy. Stockholm: IIES, Stockholm University, str. I-26.

42. Primorac, M., 20II. Local Governmentand Utility Firms' Debt. Financial Theory and Practise, 35(4), str. 443-464.

43. Rašić Bakarić, I. [et al.], 20I3. Ekonomska uspješnost gradova u Hrvatskoj - statistička analiza. Faculty of Economics and Business Zagreb Working Paper Series, I3-08, str. I-2I.

44. Rogić Lugarić, I., 20IO. Financijski aspekti položaja velikih gradova. Hrvatska javna uprava, Io(3), str. 683-708.

45. Rogić Lugarić, T., 20I2. Financiranje velikih gradova. Zagreb: Pravni fakultet Sveučilišta u Zagrebu, Studijski centar za javnu upravu i javne financije.

46. Rogoff, K., I990. Equilibrium Political Budget Cycles. The American Economic Review, 8o(I), str. 2I36.

47. Rogoff, K. i Siebert, A., 1988. Elections and Macroeconomic Policy Cycles. Review of Economic Studies, 55(I), str. I-I6. doi: I0.2307/2297526

48. Rose, S., 2006. Do Fiscal Rules Dampen the Political Business Cycle. Public Choice, I28(3-4), str. 40743I. doi: $10.1007 /$ sIII27-005-9007-7

49. Schneider, C. J., 20IO. Fighting with one hand tied behind the back: political budget cycles in the West German states. Public Choice, I42(I), str. 125-150. doi: 10.I007/sIII27-009-9480-5

50. Schuknecht, L., 200o. Fiscal policy cycles and public expenditure in developing countries. Public Choice, IO2 (I-2), str. II5-I3O.

5I. Seitz, H., 200o. Fiscal policy, deficits and politics of sub national governments: The case of German Laender. Public Choice, IO2(3-4), str. I83-2I8. doi: I0.IO23/A:I005000124300

52. Shi, M. i Svensson, J., 2003. Political Budget Cycles: A Review of Recent Developments. Nordic Journal of Political Economy, 29, str. 67-76.

53. Shi, M., i Svensson, J., 2006. Political budget cycles: Do they differ across countries and why? Journal of Public Economics, 90(8-9), str. 1367-1389. doi: 10.1016/j.jpubeco.2005.09.009

54. Snowdon, B. i Vane, H. R., 2005. Modern Macroeconomics: Its Origins, Development and Current State. London: Edward Elgar, Cheltenham. 
55. Stigler, G. J, 1984. Economics-The Imperial Science? Scandinavian Journal of Economics, 86(3), str. 3OI-3I3. doi: 10.2307/3439864

56. Škrabić, B., 2009. Determinante razvoja financijskog sustava zemalja središnje i istočne Europe. Magistarski rad. Zagreb: Ekonomski fakultet Zagreb, Sveučilište u Zagrebu.

57. Tullock, G., I972. Economic Imperialism u: J. M. Buchanan, R. D. Tollison i G. Tullock, ur. Theory of Public Choice: Political Applications. Ann Arbor: University of Michigan Press, str. 317-29.

58. Tullock, G., 1987. Public Choice u: S. N. Durlauf, ur. The New Palgrawe: Dictionary of Economics. New York: Palgrawe Macmillan, str. IO4O-IO44.

59. Udehn, L., 2003. The Methodology of Rational Choice u: S. M., Cahn, ur. The Blackwell Guide to the Philosophy of the Social Sciences. Malden: Blackwell Publishing Ltd.MA, str. I43-I66.

6o. Veiga, L. G. i Veiga, F. J., 2007. Political business cycles at the municipal level. Public Choice, I3I(I-2), str. 45-64. doi: IO.IOO7/sIII27-006-9104-2

6I. Višić, J. i Škrabić Perić, B., 20II. The determinants of value of incoming cross-border mergers \& acquisitions in European transition countries. Communist and Post-Communist Studies, 44(3), str. I73-I82. doi: IO.IOI6/j.postcomstud.20II.07.004

62. Vučković, V., 20II. Političko-poslovni ciklusi: postoje li u Hrvatskoj. Privredna kretanja i ekonomska politika, 2O(I25), str. 6I-88. 